\title{
Rural Institutions and Producer Organizations in Imperfect Markets: Experiences from Producer Marketing Groups in Semi-Arid Eastern Kenya
}

\author{
Bekele Shiferaw, Gideon Obare, and Geoffrey Muricho \\ International Crops Research Institute for the Semi Arid
}

Tropics

Research Workshop on Collective Action and Market Access for Smallholders October 2-5, 2006 - Cali, Colombia

The CGIAR Systemwide Program on Collective Action and Property Rights (CAPRi) is an initiative of the 15 centers that belong to the Consultative Group on International Agricultural Research. The initiative promotes comparative research on the role played by property rights and collective action institutions in shaping the efficiency, sustainability, and equity of natural resource systems. CAPRi's Secretariat is hosted by the International Food Policy Research Institute's (IFPRI) Environment and Production Technology Division (www.ifpri.org).

CAPRi Working Papers contain preliminary material and research results and are circulated prior to a full peer review in order to stimulate discussion and critical comment. It is expected that most Working Papers will eventually be published in some other form, and that their content may also be revised. This paper was also published as ICRISAT Working Paper no. 23 (www.icrisat.org).

Copyright (C) October 10, 2006. International Food Policy Research. All rights reserved. Sections of this material may be reproduced for personal and not-for-profit use without the express written permission of but with acknowledgment to IFPRI and ICRISAT. To reproduce the material contained herein for profit or commercial use requires express written permission. To obtain permission to reprint, contact the IFPRI Communications Division at ifpri-copyright@cgiar.org. c/o INTERNATIONAL FOOD POLICY RESEARCH INSTITUTE 


\section{ACKNOWLEDGEMENTS}

This research was undertaken with financial support from the System-wide Program on Collective Action and Property Rights Institutions (CAPRi) and ICRISAT. (This paper was also published as ICRISAT Working Paper no. 23 (www.icrisat.org)).

We have benefited from review comments and suggestions by Parthasarathy Rao,

Esther Mwangi, Heidi Hogset and Julius Okello and other anonymous reviewers. The usual disclaimers apply. 


\begin{abstract}
Many countries in sub-Saharan Africa have liberalized markets to improve efficiency and enhance market linkages for smallholder farmers. The expected positive response by the private sector in areas with limited market infrastructure has however been disappointing. The functioning of markets is constrained by high transaction costs and coordination problems along the production-to-consumption value chain. New kinds of institutional arrangements are needed to reduce these costs and fill the vacuum left when governments withdrew from markets in the era of structural adjustments. One of these institutional innovations has been the strengthening of producer organizations and formation of collective marketing groups as instruments to remedy pervasive market failures in rural economies. The analysis presented here with a case study from eastern Kenya has shown that while collective action - embodied in Producer Marketing Groups (PMGs) - is feasible and useful, external shocks and structural constraints that limit the volume of trade and access to capital and information require investments in complementary institutions and coordination mechanisms to exploit scale economies. The effectiveness of PMGs was determined by the level of collective action in the form of increased participatory decision making, member contributions and initial start-up capital. Failure to pay on delivery, resulting from lack of capital credit, is a major constraint that stifles PMG competitiveness relative to other buyers. These findings call for interventions that improve governance and participation; mechanisms for improving access to operating capital; and effective strategies for risk management and enhancing the business skills of the PMGs.
\end{abstract}

Keywords: Market imperfections, transaction costs, farmer organizations, institutions, collective action, semi-arid tropics, Kenya 


\section{TABLE OF CONTENTS}

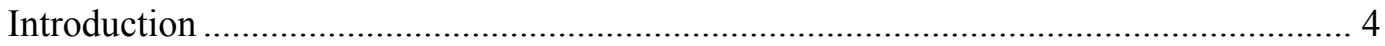

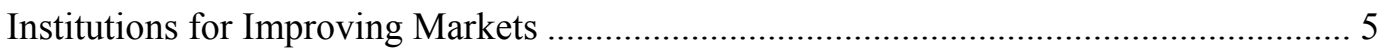

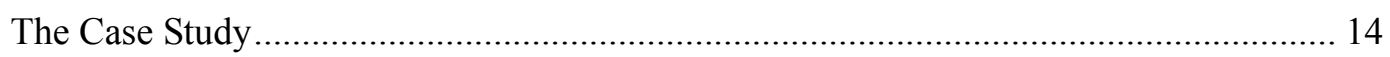

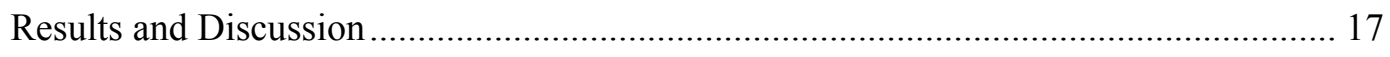

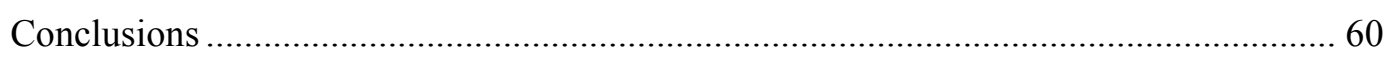

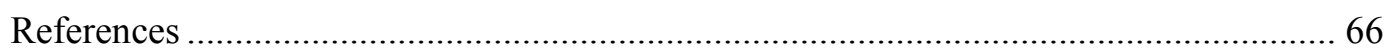




\title{
Rural Institutions and Producer Organizations in Imperfect Markets: Experiences from Producer Marketing Groups in Semi-Arid Eastern Kenya
}

\author{
Bekele Shiferaw, ${ }^{1}$ Gideon Obare, ${ }^{2}$ and Geoffrey Muricho ${ }^{3}$
}

\section{INTRODUCTION}

As part of the structural adjustment program of the 1980s and the 1990s, many subSaharan countries have liberalized their economies and developed poverty reduction strategies that are intended to open new market-led opportunities for economic growth. However, market liberalization - expected to facilitate the functioning and effectiveness of markets - have had mixed results (eg, Jayne and Jones 1997; Winter-Nelson and Temu 2002; Dorward and Kydd 2004; Fafchamps 2004). Moreover, successful implementation of structural adjustments for poverty reduction requires, among others, good infrastructure and diversified agriculture (Kydd and Dorward 2004; Dorward et al. 2004b; Dorward et al. 2005). Lack of such economic transformation after liberalization has been attributed to factors such as partial implementation of reforms and policy reversals (eg, Jayne et al. 2002; Kherallah et al. 2000; Jayne and Jones 1997) and lack of strong institutions that support market and private sector development (World Bank 2002a and 2003). In areas with limited market infrastructure, the argument for lack of economic transformation of agriculture towards more commercialized production is strongly embedded in the lack of incentives for

\footnotetext{
1 Senior Economist and Program Coordinator (Markets, Institutions, Policies and Impacts), ICRISAT, Nairobi, Kenya. Email: b.shiferaw@cgiar.org

${ }^{2}$ Associate Professor, Department of Agricultural Economics, Egerton University. Email: g.obare@cgiar.org

${ }^{3}$ Research Associate, ICRISAT, Nairobi, Kenya: Email: g.muricho@cgiar.org
} 
private sector investment and the need for proper institutions to fill the vacuum left by the withdrawal of the state.

Nonetheless, liberalization has opened a window of opportunity for smallholder producers hitherto growing diverse products and supplying small surpluses to markets. The removal of trade barriers and increased competition has opened some flexibility for farmers to choose buyers for their products and suppliers of key inputs. But high transaction costs and problems of asymmetric information continue to bedevil smallholder farmers, especially those with poor access to markets for products, inputs and services. Lack of access to market infrastructure and geographical isolation either due to remoteness or poor roads and poor communication systems limit the development of markets. Hence, smallholder producers in these areas are poorly served by agricultural traders, making local markets thin, less competitive and prices highly dependent on seasons: falling sharply at the time of harvest and increasing gradually as local supply declines. The lack of competition among buyers, low local effective demand and covariate risks limit opportunities for farmers to bargain for better prices, which leaves them to accept low prices for their produce (de Janvry et al. 1991; Kindness and Gordon 2001).

Along the market and value chain, processors and traders are constrained by low quality grain, inadequate supply and high cleaning costs whereas market intermediaries in the supply chain face high assembly costs, high market risk and cash flow problems. These factors deprive farmers the underlying incentives to produce and supply quality and differentiated products with desirable market traits in addition to their inability to penetrate high value niche markets (Jones et al. 2002). This indicates that small-scale, dispersed and unorganized producers are unlikely to exploit market opportunities as they cannot attain the 
necessary economies of scale and lack bargaining power in negotiating prices. This reduces their ability to compete with well established large scale producers and farmers in morefavoured areas to harness available and emerging market opportunities (Johnson and Berdegue 2004). One viable strategy for such producers would be to evolve new collective forms of organization that would help them reduce transaction costs and benefit from better bargaining power in marketing their produce and procuring production inputs.

Producer or farmer organizations refer to the various forms of organizations that perform diverse functions such as analysis, advocacy, economic (production and marketing) and local development (Stockbridge et al. 2003). They are grounded on the principle of collective action among potential beneficiaries. Collective action occurs when individuals voluntarily cooperate as a group and coordinate their behaviour in solving a common problem. In broad terms, collective action may be defined as action taken by a group (either directly or on its behalf through an organization) in pursuit of members' perceived shared interest (Marshall 1998), which fits well in the traditional African setting. In the absence of well functioning markets, African farmers have traditionally relied on kinship and other forms of reciprocal relationships in production, marketing and other social activities (Fafchamps and Minten 1999; Gabre-Madhin 2001). There is a potential that such informal institutions and relationships can form the basis for enhancing market access and entrepreneurial skills through collective action. However, collective action in marketing requires closer coordination of production and postharvest activities to ensure delivery of high quality and homogeneous products. Moreover, new forms of organization among small and spatially dispersed producers involve transaction costs and require good leadership and development of new skills in business and agro-enterprise development. The negative 
experiences of cooperatives in the past attest to the importance of these factors in farmer organization, management and resilience (Lele 1981).

If new forms of organization and market institutions are going to help reduce transaction costs and enhance market opportunities for the poor, there is a need to understand how such collective action evolves and how it is sustained; the determinants of farmer participation; alternative forms of organization that may enhance performance and effectiveness; and the complementary institutions and the policy support needed for the effectiveness of collective marketing groups.

This paper aims to review the conceptual issues surrounding imperfect markets in smallholder agriculture and the role that institutional and organizational innovations can play in improving the performance of rural markets. With a case study of producer marketing groups in eastern Kenya, the paper offers new insights on the potentials and constraints of rural institutions in providing market services. The analysis highlights marketing outcomes and the potential sources of differential success of marketing groups in relation to marketing and other stated functions. The paper is organized as follows: Introduction of background; reviews market institutions and their emerging roles in remedying market imperfections or failures in rural areas; Outlines the methodological approach used in the case study; discussion of the key results, presents analyses of policy and institutional issues that affect the development of collective marketing groups. The main lessons and policy conclusions are found in the concluding section. 


\section{INSTITUTIONS FOR IMPROVING MARKETS}

\section{Market imperfection and the role of institutions}

Institutions are defined in many different ways. The most widely quoted one is by North (1990) which defines institutions as humanly devised constraints, made up of formal constraints (ie, rules, laws, constitutions), informal constraints (ie, norms of behaviour, conventions and self-imposed codes of conduct) that structure human interactions, and their enforcement characteristics. These constraints and the technology employed determine the transaction and transformation costs that add up to the production and marketing costs. Following North (1990), Dorward et al. (2005) define institutions as "rules of the game" that define the incentives and sanctions affecting people's behaviour and distinguish institutional arrangement as sets of rules and structures that govern particular contracts, and the context within which the contracts are governed. The World Bank (2002a) offers a working definition of institutions as rules, enforcement mechanisms and organizations that promote market transactions. These definitions indicate that institutions provide multiple functions to markets; they transmit information, mediate transactions, facilitate the transfer and enforcement of property rights and contracts, and manage the degree of competition. Along with these concepts, we define market institutions as rules of the game, enforcement mechanisms and organizations that facilitate market interaction, coordination, contract formation and enforcement.

Market failures are caused by asymmetric information, high transaction costs and imperfectly specified property rights. These market deficiencies are more pronounced in rural 
areas with under-developed road and communication networks and other market infrastructure. Where supporting market institutions are lacking, rural markets in areas with low market infrastructure tend to be very thin and imperfect. In the absence of institutions that help to coordinate marketing functions or to link producers to markets, the associated high transportation costs and transaction costs undermine the processes of exchange (Kranton 1996; Gabre-Madhin 2001) and result in limited or localized markets with little rural-urban linkages (Chowdhury et al. 2005). In such circumstances, households produce only a limited range of goods and services for their own consumption because social protection for food security is not provided through markets and government interventions (de Janvry et al. 1991). Shocks and vulnerability to production risk (ie, weather, pests and sickness) and market risk (ie, price) that seem systemic to agriculture also lead to imperfect markets and transaction failures (Dorward and Kydd 2004).

When high transaction costs, asymmetric information and incomplete property rights impede the functioning of markets, market players fail to undertake profitable investments (due to the absence of complementary investments) leading to coordination failures that hinder market functions (Dorward et al. 2003; Dorward et al. 2005; Poulton et al. 2006). Thus coordination failure along the production-to-consumption value chain may explain constrained agricultural development and the prevalence of a low equilibrium trap, ${ }^{4}$ which is a big challenge to policy (Dorward et al. 2003). Overcoming the effects of such market imperfections in agricultural input and output markets would therefore require a deliberate attempt to strengthen institutions that promote coordination of market functions, reduce

\footnotetext{
${ }^{4}$ The low equilibrium trap is a steady state situation resulting from low levels of investment that tend to sustain imperfect markets and poverty (Hoff 2001).
} 
transaction costs and integrate markets to facilitate a continual transition to a higher level equilibrium (World Bank 2002b).

Various private and public sector market-supporting institutions and institutional arrangements have been proposed to bridge market imperfections, reduce transaction costs, enhance opportunities for the poor in markets and to make the market systems more inclusive and integrated (World Bank 2002a). Among the potential market-supporting institutions can that enhance market functions in rural areas are farmer organizations such as Producer Marketing Groups (PMGs). Their potential in this process lies in enabling contractual links to input and output markets (Coulter et al. 1999); promoting economic coordination in liberalized markets (Rondot and Collion 1999); and in leveraging market functions for smallholder farmers. However, their success in this process depends on their ability in conveying market information; coordinating marketing functions; defining and enforcing property rights and contracts; facilitating smallholder competitiveness in markets (World Bank 2002a), and more critically in mobilizing their members to engage in markets.

\section{Farmer organizations and marketing}

Historically, farmer cooperatives were introduced in sub-Saharan Africa (SSA) during the colonial period for the purpose of promoting production of cash crops by peasant farmers (Hussi et al. 1993). After independence, many governments as well as donors promoted cooperatives and other rural organizations as a potential source of decentralized grassroots participation in agricultural credit, input and commodity markets (Lele and Christiansen 1989; Hussi et al. 1993). Their performances were mixed. In Kenya, for example, semiautonomous agencies - such as the Kenya Tea Development Authority (KTDA), and the 
coffee and dairy cooperatives - were important to the growth of smallholder production, while some parastatals and cooperatives showed mediocre record. The mediocre performances were attributable to technological problems and poor management (Wolf 1986; Lele and Christiansen 1989)

Generally, the performance of farmer cooperatives in relation to poverty reduction and provision of essential services has not been exemplary (Lele 1981; Hussi et al. 1993; Akwabi-Ameyaw 1997). Supported by governments, they functioned primarily as service cooperatives rather than as business enterprises owned and managed by the members. They were not allowed sufficient marketing margins to cover their operational expenses and could, therefore, not evolve into commercially viable enterprises. This compromised their inherent character as member-controlled organizations which in turn discouraged member participation and eroded confidence in the leadership. With structural adjustment and economic reforms, many of the service cooperatives lost their special protection from the state, which further reduced their viability in the ensuing competitive environment (Lele 1981).

For cooperatives and rural organizations to be effective in serving a broad set of socio-political and economic objectives of small producers, new policies and institutional reforms are needed to facilitate their transformation from public sector service providers to private sector enterprises with clear business plans. With hindsight, farmer organizations tend to succeed only when: farmers can manage them autonomously with minimal government interference; farmers participate actively in decision-making at every stage of the process; and their cooperative activities are profitable (World Bank 1995). 
A strong justification for farmer organizations is their potential to play a critical role in both the delivery and coordination of services to smallholder producers (Dorward et al. 2004b). They can facilitate collective marketing of agricultural outputs that will help reduce transaction costs related to the marketing of agricultural inputs and small marketable surplus emanating from a large number of widely dispersed small producers. Collective marketing allows small-scale farmers to spread the costs of marketing, enhance their ability to negotiate for better prices, and improve their market power. Furthermore, climatic variability in semiarid areas increases the variability of supply and prices because effective demand is limited, and small-scale farmers are often unable to sell to consumers outside of their local markets. Through coordination of marketing activities, PMGs could facilitate access to better markets, reduce marketing costs, and synchronize buying and selling practices to seasonal price conditions. PMGs can shorten the marketing chains by linking producers more directly to the upper end of the marketing chain as shown in Figure 1. 
Figure 1--Marketing channels and value chains for grains and the role of PMGs.
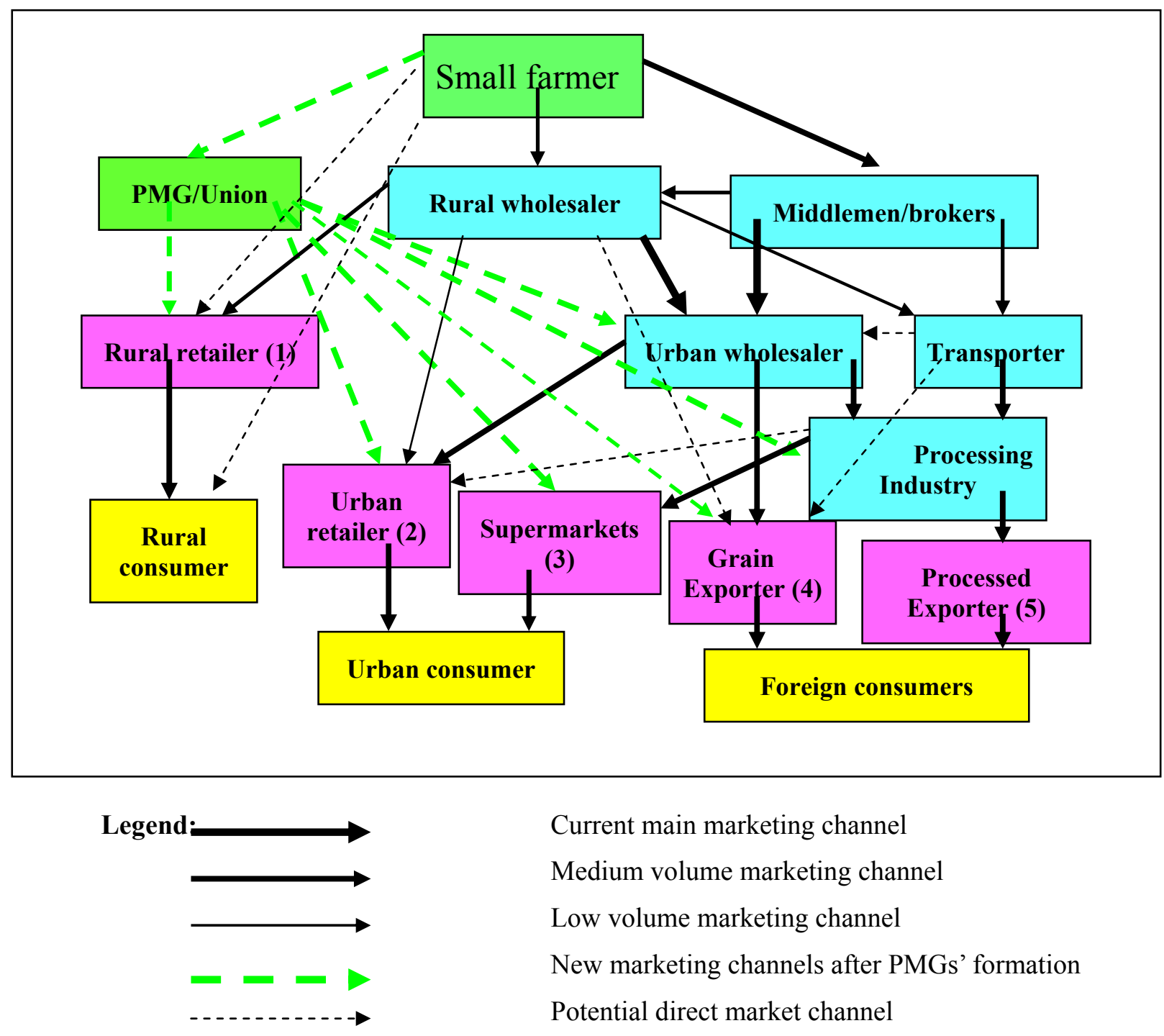

Current main marketing channel

Medium volume marketing channel

Low volume marketing channel

New marketing channels after PMGs' formation

Potential direct market channel

Well organized farmers will be able to bypass brokers or assemblers, rural

wholesalers and transporters who now procure grain directly from farmers, and connect directly with the urban high value retailers and processors or exporters. This can be done through various contractual arrangements, including outgrower schemes or postharvest bulk delivery 
In many rural areas, commercial inputs are either unaffordable or smallholder farmers face high transaction costs, which further undermines their ability to use such inputs. The high input costs for small quantities resulting from high transaction and transportation costs are likely to make investments in commercial inputs uneconomical to many smallholder farmers. Farmer marketing groups can however facilitate input and output markets access and service delivery, thus promoting commercial activities and technological change in agriculture (Kindness and Gordon 2001). However, for these organizations to be beneficial to farmers, governments need to provide complimentary public goods that would empower small producers to participate in markets (Kelly et al. 2003).

\section{Evolution and development of farmer marketing groups}

Farmer marketing groups as an outcome of collective action are unlikely to emerge on their own (Johnson et al. 2002). The need for collective action depends on the resource type, degree of spatial integration and the time required in achieving the desired outcomes. Controlling for conducive environment and political leaderships, White and Runge (1995) have shown that groups will emerge and survive where a "critical mass" of individuals have practical knowledge of the potential gains from collective action, but that in the short term emergence can be constrained by landscape factors that affect the potential net gain, and socio-cultural factors that influence the cost of constructing the new institution. It follows therefore that both micro and macro factors are important determinants of the evolution and the need for collective action. Additionally, an individual's choice to participate in collective action will depend on his/her expectation of other members' behavior. 
Collective action in marketing is likely to occur if expected benefits from lower business transaction costs, better prices for inputs and outputs and/or empowerment and capacity enhancement outweigh the associated costs of complying with collective rules and norms. If the expected cooperation benefits are lower than the expected costs, households are unlikely to participate in group marketing activities. Successful collective action based on membership will, therefore, depend on the potential that group action will improve the members' expected net benefit streams above and beyond what can be achieved without such collective action. In semi-arid areas where spatially dispersed farm households produce small quantities for markets, individual net gain from collective marketing is likely to be low and unlikely to outweigh the costs unless the size of the group is large enough to minimize unit costs. This observation points to the fundamental role of improving agricultural productivity and reducing production risk in these areas so as to create opportunities for market development.

Nevertheless, the costs and benefits are likely to differ across households depending on location, volume of production, asset endowment, education and managerial skills (Staal et al. 1997; Hollway and Ehui 2002; Kerr et al. 2002). Since the benefits of farmer marketing groups are unlikely to be equally distributed, some households may not find them useful unless some interventions are designed to enhance their participation - suggesting that individual participation in farmer organizations is an endogenous process that may vary across households.

The potential for accessing essential services to improve agricultural incomes and tapping economic opportunities will act as a strong incentive for anyone contemplating membership. Existing skills/experience of members in relation to what is required to 
undertake joint activities; internal cohesion and membership driven agenda; and the ability to effectively integrate into a wider commercial economy will determine the effectiveness of collective marketing activities (Stringfellow et al. 1997). This implies that measures designed to enhance farmer marketing group capacities will contribute to the success of producer marketing groups. Therefore programs that are geared towards facilitating groups' self reliance and enhancing organizational and management skills are likely to equip groups with the capacity to forge effective business interactions with the private sector for agricultural development (Bingen et al. 2003).

Despite the potential gains from collective action, individual cooperative behavior may not be translated into collective action unless other potential beneficiaries agree to cooperate and do likewise. The presence and assurance of trust between and among individuals facilitates the potential for reciprocity and emergence of cooperative behavior (Runge 1981; White and Runge 1995). It follows, thus, that interventions which enhance trust among members in a group, including laws of engagement and operational democracy, are likely to contribute to successful collective action. The functional orientation of farmer groups and their internal features are also important determinants of the success of farmer organizations (Coulter et al. 1999). Larger groups may be less successful than small groups in furthering their interest but only up to a certain level. This is mainly because the transaction and managerial costs of cooperation increase faster than the gains as group size increases beyond a certain level (Hussi et al. 1993), which means that optimal group size will depend on the type of activity and the features of the group. 


\section{THE CASE STUDY}

In order to examine the relevance of the above reviewed conceptual issues and assess the constraints and opportunities for farmer organizations to facilitate market access for the poor, a study was conducted in two districts of eastern Kenya (Mbeere and Makueni). The two districts are located in part of the larger semi-arid lands where market infrastructure is poor (Appendix 1) and farmers produce limited marketable surplus. They are characterized by low density paved roads and limited access to major marketing centers. Although climatic variability is a typical characteristic of these areas with recurrent droughts, smallholder agriculture is almost entirely dependent on rains.

The study capitalizes on two rounds of data sets collected in the two districts: a baseline and a follow-up survey. The baseline survey of 400 households (240 in Mbeere and 160 in Makueni) was undertaken in 2003 before the PMGs were formed as part of a research project that aimed to test alternative institutional arrangements for improving market access for smallholders. The households were randomly sampled from a list of all households in the targeted villages. Farmers were sensitized and assisted ${ }^{5}$ to form PMGs with the view to test the potential of these groups to improve market access for small farmers. Communities managed to voluntarily establish five PMGs in each of the two districts. Consequently, the groups were formally registered and provided a certificate of legal constitution issued by the Ministry of Culture and Social Services. After registration some of the households who had expressed interest in joining the groups decided not join. From the initial sample of 400

\footnotetext{
${ }^{5}$ The form of assistance provided included bringing the farmers together to discuss production and marketing strategies for dryland legumes; to identify production and marketing constraints and opportunities; training in quality seed production and marketing; and provision of information in organizing marketing groups. No direct subsidies or incentives were provided to farmers to join groups.
} 
households, the distribution of members and non-members was decided later, after the PMGs were established with committed members who paid the registration fees and/or annual contributions to the group (Table 1).

Table 1--Household sampling and sample sizes for 2003 and 2005 surveys

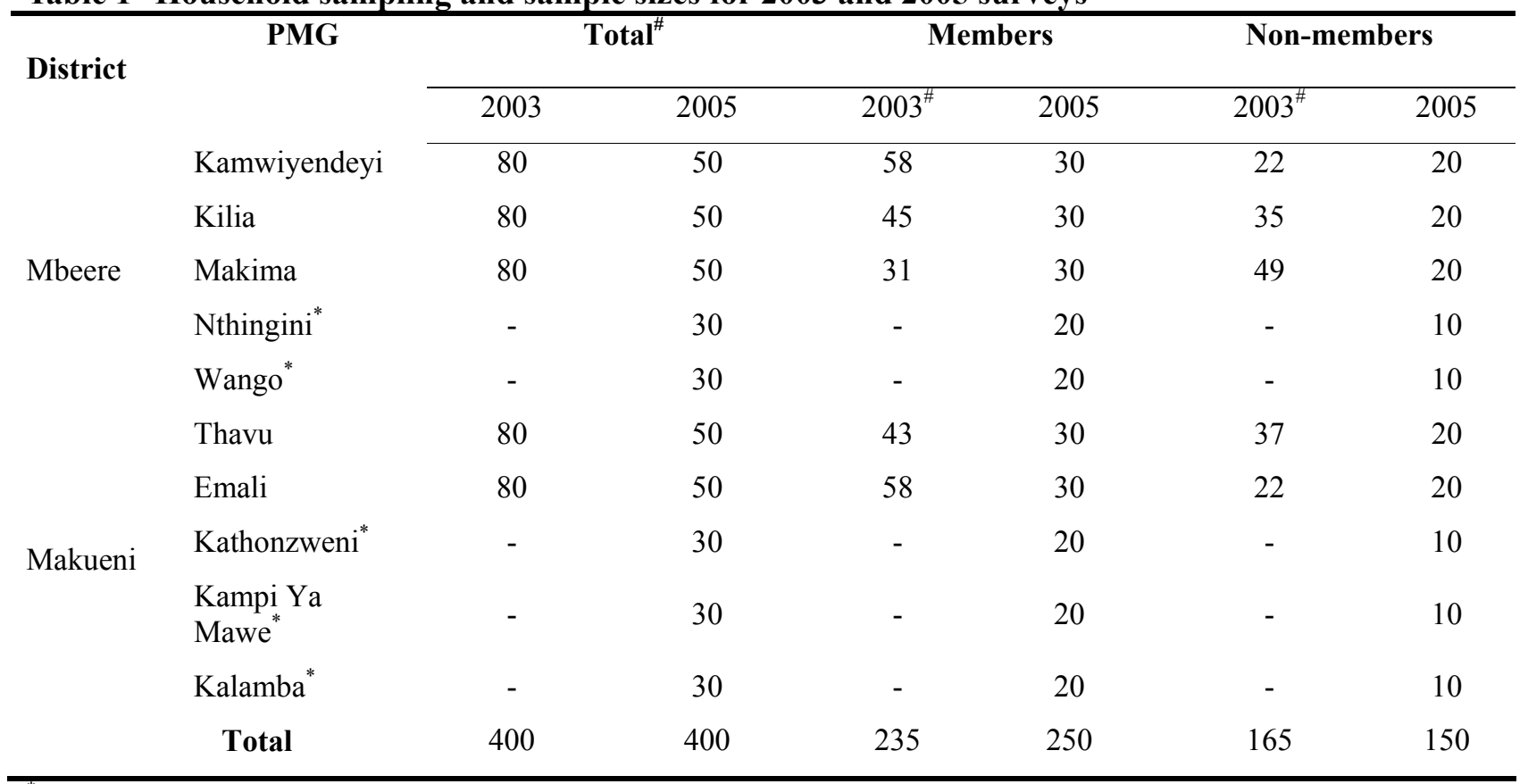

*A baseline survey was not conducted in these PMG villages in 2003 because they were included in the project only after the survey was conducted in the initial five target villages.

${ }^{\#}$ The number of PMG members in 2003 is based on later classification of the baseline data into PMG members and non-members after the PMGs were clearly established. The 2005 survey covered all the PMG villages and sampled from members and non-members.

Source: Household surveys (2003 and 2005).

Information collected during the baseline survey included poverty indicators;

production levels of dryland crops; market participation by households; and adoption of agricultural technologies.

During the follow-up survey conducted in 2005, data were collected at three levels: the community or village, the PMG and the farm household. At the community or village level, a total of 20 communities/villages (two from each PMG) were purposively selected for the survey based on villages that had the highest number of registered members in their 
respective PMGs. Thereafter, a group of about nine gender-balanced key informants were selected from each village based on peer perception and the village chief's advice on their ability to provide quality information about the village. A semi-structured questionnaire was administered to the informants to obtain data on demographic and resource use, socioeconomic conditions, trends and the overall economic profiles of the PMG villages. At the PMG level, all the ten PMGs were surveyed separately. Based on advice from community elders and the village chief, a group of five to seven respondents comprising of PMG management and ordinary members were selected from each PMG as key informants. A semi-structured questionnaire was administered to obtain data on the objectives and aspirations of the groups when they were formed; general group characteristics (eg, size and composition, frequency of meetings and capital); asset ownership (eg, store, weighing scales and operating capital); credit access; bulking and marketing; governance; major constraints limiting group performance and planned activities.

At the household level, data were collected on socioeconomic and demographic characteristics, crop and livestock production and marketing activities, household assets, credit and savings, access to information and participation in collective marketing or awareness of collective marketing groups and perception of anticipated benefits among nonmembers. A total of 400 randomly selected households in the PMG villages, comprising of 250 members and 150 non PMG members, were surveyed (210 from Mbeere district and 190 from Makueni district). These 400 randomly selected households included 250 households from the baseline survey. ${ }^{6}$

\footnotetext{
${ }^{6}$ This sub-sample consists of 150 households re-sampled from 235 baseline households that had remained PMG members and 100 households re-sampled from 165 households that had remained non-PMG members (see
} 
The primary data were subjected to qualitative and quantitative analyses. Simple descriptive statistics were used to analyze the socioeconomic and biophysical profiles of the PMG villages. In particular, they were used to assess the prevalence and levels of poverty, market participation and resource management conditions in the PMG villages. The PMG data were analyzed to understand market functions and performance of PMGs; to determine governance problems and the level of collective action; to identify indicators of collective action; and the effectiveness of collective action in marketing functions and the associated factors that affect group performance. Household data were used to examine the marketing channels and market actors along the value chain, and to establish the market shares, volumes and prices offered by different agents to farmers. An econometric model was estimated to determine factors that influence unit price of point transactions; to establish whether prices offered to smallholder farmers by different market participants and particularly by the PMGs, controlling for other factors, would be significantly different; and to test whether PMGs pay higher mean prices with lower variance than other buyers.

\section{RESULTS AND DISCUSSION}

\section{Socioeconomic profiles of PMG villages}

The overall level of market access in the PMG villages is very poor. The level of accessibility is relatively good during the dry seasons but the roads are usually impassable during the rainy season. The average distance from the PMG stores to the nearest market was

Table 1). The panel data can be used to evaluate potential changes on marketing activities and livelihoods. Due to space limitations, this analysis is not pursued in this study. 
about $9 \mathrm{~km}$ and ranged between $0 \mathrm{~km}$ (eg, Makima and Kathonzweni) to $20 \mathrm{~km}$ (eg, Kilia), while the distance from the PMG stores to the district commercial centre was between $11 \mathrm{~km}$ for Kampi Ya Mawe (KYM) and $150 \mathrm{~km}$ for Nthingini (Table 2 and Appendix 1).

Table 2--Socioeconomic profile of the PMGs

\begin{tabular}{|c|c|c|c|c|c|c|}
\hline PMG & $\begin{array}{l}\text { Group } \\
\text { size }\end{array}$ & $\begin{array}{l}\text { Female } \\
\text { members } \\
(\%)\end{array}$ & $\begin{array}{l}\text { Initial } \\
\text { capital } \\
\left(\text { KSH }^{\#}\right)\end{array}$ & $\begin{array}{l}\text { Nearest grain } \\
\text { wholesaler } \\
\text { market }(\mathbf{k m})\end{array}$ & $\begin{array}{l}\text { Distance to } \\
\text { district } \\
\text { commercial } \\
\text { centre }(\mathbf{k m})\end{array}$ & $\begin{array}{l}\text { Distance to } \\
\text { Nairobi } \\
(\mathbf{k m})\end{array}$ \\
\hline \multicolumn{7}{|l|}{ Mbeere district } \\
\hline Wango & 116 & 62 & 8170 & 14 & 100 & 101 \\
\hline Nthingini & 123 & 75 & 2620 & 11 & 150 & 280 \\
\hline Kilia & 184 & 61 & 2800 & 20 & 80 & 118 \\
\hline Kamwiyendeyi & 112 & 67 & 2640 & 4 & 120 & 93 \\
\hline Makima & 50 & 40 & 17700 & 0 & 42 & 160 \\
\hline \multicolumn{7}{|c|}{ Makueni district } \\
\hline Emali & 164 & 46 & 16000 & 9 & 50 & 118 \\
\hline Thavu & 120 & 17 & 4062 & 7 & 30 & 160 \\
\hline Kathonzweni & 68 & 75 & 600 & 0 & 25 & 168 \\
\hline Kalamba & 47 & 93 & 600 & 15 & 26 & 134 \\
\hline $\mathrm{KYM}^{*}$ & 65 & 49 & 1480 & 11 & 11 & 150 \\
\hline Average & 105 & 58 & 5667 & 9 & 63 & 148 \\
\hline
\end{tabular}

"Kampi Ya Mawe

${ }^{\#}$ Kenyan Shilling

Source: PMG survey 2005

This confirms the high level of transportation costs and transaction costs faced by small producers in this area.

The proportion of households that produced surplus cereals and legumes were generally higher in Mbeere district than in Makueni. However, the proportion of households 
that produced surplus cereals and legumes significantly declined when 2004/05 is compared to the situation in 1995 . This may be attributed to drought that prevailed in 2004, which drastically reduced market participation (Table 3).

Table 3-- Socioeconomic profile of PMG villages

\begin{tabular}{|c|c|c|c|c|c|c|}
\hline \multirow[t]{2}{*}{ Issue } & \multicolumn{2}{|l|}{ Mbeere } & \multicolumn{2}{|l|}{ Makueni } & \multicolumn{2}{|l|}{ Total } \\
\hline & $\begin{array}{l}10 \text { years } \\
\text { before }\end{array}$ & 2005 & $\begin{array}{l}10 \text { years } \\
\text { before }\end{array}$ & 2005 & $\begin{array}{l}10 \text { years } \\
\text { before }\end{array}$ & 2005 \\
\hline $\begin{array}{l}\text { Produce surplus for markets } \\
\text { (cereals), \% }\end{array}$ & 44 & 19 & 29 & 10 & 36 & 14 \\
\hline $\begin{array}{l}\text { Produce surplus for markets } \\
\text { (legumes), \% }\end{array}$ & 44 & 16 & 22 & 7 & 33 & 11 \\
\hline Using farmyard manure, $\%$ & 30 & 67 & 38 & 65 & 33 & 66 \\
\hline Using mineral fertilizer, $\%$ & 1 & 5 & 0 & 3 & 1 & 4 \\
\hline Using field pesticides, $\%$ & 22 & 75 & 25 & 46 & 24 & 61 \\
\hline Using storage pesticides, $\%$ & 21 & 70 & 41 & 73 & 31 & 72 \\
\hline
\end{tabular}

Source: PMG survey 2005

In contrast, a high proportion of households now use fertilizer and manure compared to 10 years earlier. The proportion of households in Mbeere using fertilizer rose from 1 to 5 percent over the past 10 years. In Makueni this proportion increased from 0 to 3 percent over the same period. Drought risk is a major factor limiting fertilizer use on rainfed crops. It reduces total production and hence marketed surplus of food crops grown in these areas. A comparison between cereal and legume surplus producing households reveals a relatively higher percentage of households producing surplus cereals than legumes. This could be attributed to most legumes being susceptible to drought compared to cereals and also to a proportionately larger land area devoted to cereals than legumes. 
The level of poverty in the PMG villages is very high. A significant proportion (60-70 percent) of households is below the poverty line ${ }^{7}$ and relies primarily on subsistence agriculture. Landlessness is relatively low (1-11 percent) but land productivity is limited by biophysical factors and low level of technology adoption (Table 4).

Table 4--Poverty profiles and technology adoption in PMG villages

\begin{tabular}{|c|c|c|c|c|c|c|}
\hline \multirow[t]{2}{*}{ Issue } & \multicolumn{2}{|c|}{ Mbeere district } & \multicolumn{2}{|c|}{ Makueni district } & \multicolumn{2}{|c|}{ Both districts (mean) } \\
\hline & $\begin{array}{l}10 \text { years } \\
\text { before }\end{array}$ & 2005 & $\begin{array}{l}10 \text { years } \\
\text { before }\end{array}$ & 2005 & $\begin{array}{l}10 \text { years } \\
\text { before }\end{array}$ & 2005 \\
\hline $\begin{array}{l}\text { Average number of households } \\
\text { per village }\end{array}$ & 199 & 283 & 68 & 115 & 134 & 199 \\
\hline Landless households (\%) & 12 & 11 & 0 & 1 & 6 & 6 \\
\hline $\begin{array}{l}\text { Households owning local cows } \\
(\%)\end{array}$ & 69 & 57 & 53 & 59 & 61 & 58 \\
\hline $\begin{array}{l}\text { Households owning improved } \\
\text { cows }(\%)\end{array}$ & 0 & 9 & 3 & 3 & 2 & 7 \\
\hline Households owning oxen (\%) & 62 & 49 & 47 & 42 & 54 & 45 \\
\hline Households owning sheep (\%) & 44 & 24 & 42 & 22 & 43 & 23 \\
\hline Households owning goats $(\%)$ & 78 & 74 & 79 & 83 & 79 & 78 \\
\hline
\end{tabular}

Source: PMG survey 2005

The higher level of landlessness (11 percent) in Mbeere district is attributable to high population density and some immigration from neighboring districts like Embu and Kirinyaga who are attracted by the farming opportunities on government owned land schemes. About 54 and 43 percent of the households owned oxen and sheep in 1995 respectively. However, in 2005 these proportions declined to 45 and 23 percent. This could be a reflection of increasing scarcity of grazing lands due to population growth and also due

\footnotetext{
${ }^{7}$ The key informants in each village were asked to state a monthly income that would define the local poverty line based on average family sizes in the areas. The mean estimated household poverty line was Ksh 5075 per month. This translates to about Ksh 31 per person per day, which is equivalent to USD $0.44(\$ 1=\mathrm{Ksh} 70)$. This is lower than the rural poverty line per capita income of Ksh 41 (\$0.6) defined by the government of Kenya (Republic of Kenya 2000).
} 
to some level of distress-selling of livestock due to recurrent droughts. The decline in ownership of oxen and the proportion of households who lack these assets (55 percent) is particularly damaging as land is primarily cultivated using oxen-drawn ploughs. Goats were owned by about 78 percent of households in both periods which shows that they are a popular form of investment in the semi-arid areas.

\section{Aspirations of PMGs}

The stated objectives of the PMGs ranged from better prices for their produce, access to inputs, development of business skills, knowledge sharing and transformation to business entities where membership can acquire shares. Obtaining better prices for local produce was the most frequently stated objective pursued by all PMGs followed by development of business skills ( 50 percent), access to better inputs ( 40 percent), increased commercialization of production (30 percent), transformation to business entities (10 percent) and sharing knowledge and information (10 percent) (Table 5).

Table 5--Objectives and aspirations of PMGs

\begin{tabular}{ll}
\hline Stated objective & $\%$ cases $(\mathrm{n}=10)$ \\
\hline Obtain better prices & 100 \\
Access training and other assistance & 50 \\
Access improved seed and other inputs & 40 \\
Increased commercialization of production & 30 \\
Establish business entities with share capital & 10 \\
Share knowledge and information & 10 \\
\hline
\end{tabular}

$\mathrm{n}=$ number of PMGs.

Source: PMG survey 2005

Low and variable grain prices and high transaction costs for local produce seem to drive the interest to work as a group. 
Grain prices fluctuate significantly according to local supply and demand conditions in local markets. For example, pigeonpea prices were lowest during harvesting (July September) and highest during planting period (October - December) (Figure 2).

Figure 2--Seasonal price fluctuations for dry pigeonpea (Ksh/kg)

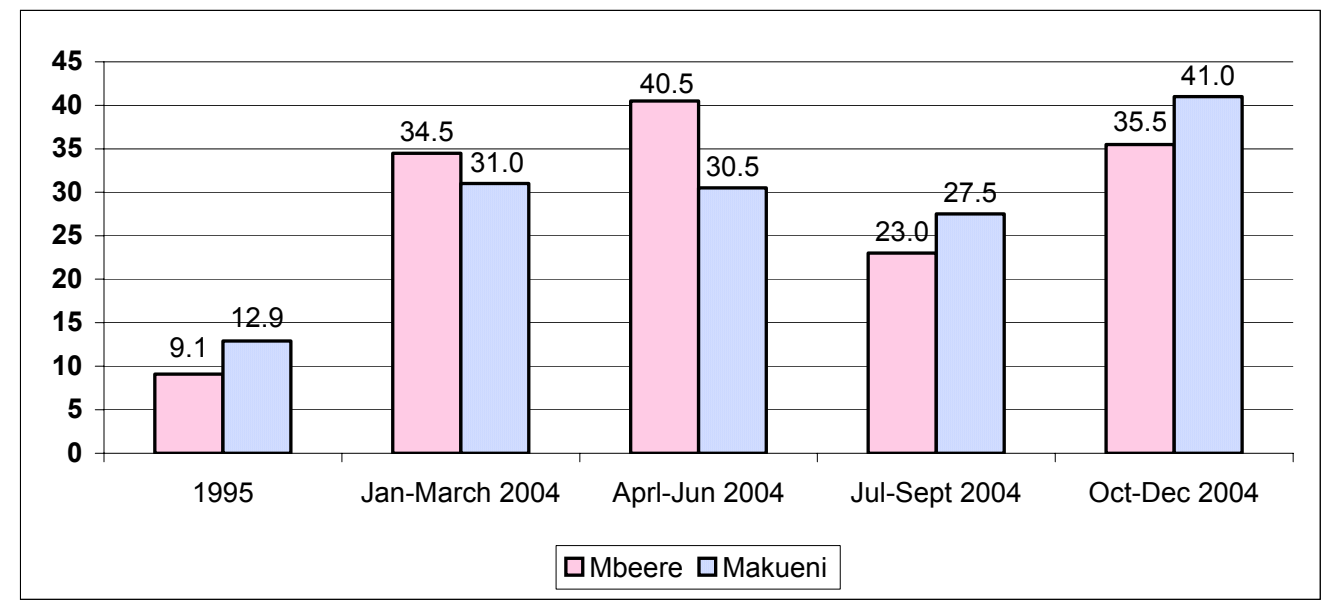

Source: Community survey 2005

The average price variation was about Ksh 13.00/kg. Accordingly maize prices were quite low (January - March) coinciding with the harvest of the short rains season crop followed by the harvest of the main rains season crop (July - September), but higher during the intervening periods when local supply is limited (Figure 3). 
Figure 3--Seasonal price fluctuations for maize $(\mathrm{Ksh} / \mathrm{kg})$

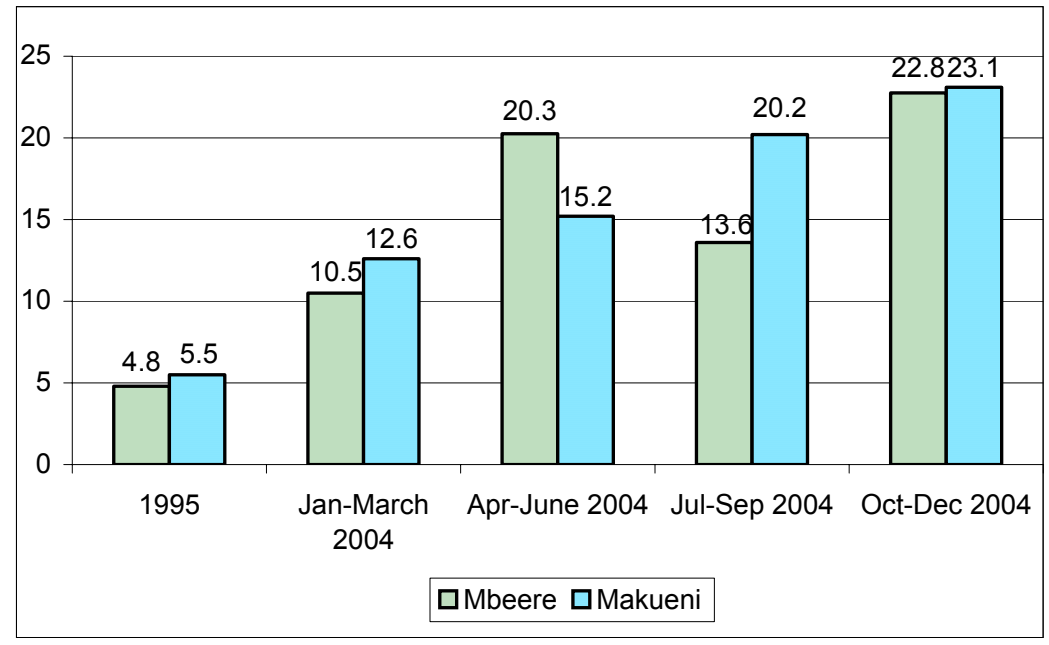

Source: Community survey 2005

The mean maize price variability was Ksh 11.30. Although these price fluctuations can be explained by the supply and demand conditions, the results also reflect the vulnerability of farmers in marginal areas to price variations which is aggravated by the recurrent droughts.

Half the PMGs aspire to access training in business and entrepreneurial skills for agribusiness and enterprise development. This is consistent with the need to manage the PMG business enterprises to enhance economic efficiency and competitiveness. The stated objective of access to commercial inputs and commercialization of agriculture are correlated and show that smallholders are keen to benefit from market opportunities. Some of the PMGs plan to establish a business enterprise with share capital, a long term goal that they may move towards as collective action becomes more effective.

When asked whether they had achieved their stated objectives, a majority of the PMGs reported that they had partly achieved them while those that had not achieved any, were working towards those goals despite several constraints. The reasons for non- 
achievement of the objectives included lack of credit, lack of ready markets, drought, poor PMG leadership and conduct of members, lack of capacity to identify and collect information and price fluctuations in that order of descending importance. The groups were further asked whether they intended to expand group functions into new directions. Several of them indicated their willingness to broaden operations by expanding into other related activities. In order of importance (measured by median rankings), the PMGs aspire to participate in the marketing of agricultural inputs (1.5), marketing of alternative high value crops (eg, vegetables and groundnuts) (2.5), watershed management (3.5) and value addition (4.5) (Table 6).

Table 6--Ranking of PMG interests and priorities to expand group activities (where $1=$ most important)

\begin{tabular}{llll}
\hline Activity & Mbeere (n= 5) & Makueni (n= 5) & Total $(\mathbf{n}=\mathbf{1 0})$ \\
\hline Agricultural input marketing & $3.0(2)$ & $1.8(1)$ & $2.4(1.5)$ \\
$\begin{array}{l}\text { Marketing new high value } \\
\text { crops }\end{array}$ & $3.4(4)$ & $21.6(2)$ & $12.5(2.5)$ \\
Watershed management & $3.4(4)$ & $2.8(3)$ & $3.1(3.5)$ \\
Value addition or processing & $6.8(8)$ & $3.0(3)$ & $4.9(4.5)$ \\
Recruiting more members & $4.6(3)$ & $6(6)$ & $5.3(5)$ \\
Live animals & $5.8(6)$ & $24.8(7)$ & $15.3(6)$ \\
Marketing livestock products & $24.4(7)$ & $24(6)$ & $24.2(6)$ \\
\hline
\end{tabular}

Figures in parenthesis are medians; $\mathrm{n}=$ the number of PMGs.

Source: PMG survey 2005

Although there is variation in the rankings on some of the activities across districts, the results suggest that the PMGs intend to diversify more into linked activities where they have gained experience and skills, with limited interest to establish backward linkages along the 
pre-production to marketing and consumption value chain (eg, collective watershed management).

\section{Governance of PMGs}

An important aspect of governance of PMGs is their constitution (by-laws) that define the norms of operations, the roles and responsibilities of various organs and members versus the management that oversees the running of the PMGs on behalf of members. All the PMGs had written by-laws governing the running of their groups. The by-laws stressed more on the obligations of the members to the group but were relatively silent on the obligations of the group to members. For example, the by-laws require that members sell their grain through the PMG, make requisite payments and/or contributions, prioritize farming of marketable crops (eg, pigeonpea) and contribute actively to the development of the group. Successful governance can be inferred from the level of adherence to the by-laws. On average 77 percent of active members abided by established by-laws. Violations of by-laws was associated with a number of reasons including ignorance about the by-laws, cash constraints to honor their payment obligations, lack of trust in the PMG leadership, and lack of commitment to the PMG cause (Table 7).

Table 7--Reasons PMG members state for not following by-laws.

\begin{tabular}{lc}
\hline Reason & \% of cases \\
\hline Lack of awareness of by-laws & 63 \\
Lack of trust in group leadership and vision & 63 \\
Too busy with other commitments & 38 \\
Cash constraints (to pay PMG fees) & 38 \\
Lack of commitment to PMG goods & 13 \\
\hline
\end{tabular}


It was stated that those members who violated the by-laws were either fined or expelled, especially if they were repeat offenders.

The PMGs had executive committees that were elected through a non-secret vote counting process and given the responsibility of running the affairs of the PMGs on behalf of the members. ${ }^{8}$ The membership of these committees included the chairperson, vice chairperson, secretary, vice secretary, treasurer, vice treasurer, marketing representative and a varying number of ordinary members. The mean annual executive meetings were 15 with a median of 12 (Table 8).

Table 8-- PMG meetings and attendance levels in two districts.

\begin{tabular}{lccc} 
Meeting type & Mbeere $(\mathbf{n}=\mathbf{5})$ & Makueni $(\mathbf{n}=\mathbf{5})$ & Total $(\mathbf{n}=\mathbf{1 0})$ \\
\hline $\begin{array}{l}\text { Executive meetings since } \\
\text { establishment }\end{array}$ & $16(12)$ & $14(12)$ & $15(12)$ \\
$\begin{array}{l}\text { Executive meetings attendance } \\
(\%)\end{array}$ & 72 & 65 & 69 \\
$\begin{array}{l}\text { General assembly meetings since } \\
\text { establishment }\end{array}$ & $7(5)$ & $9(6)$ & $8(6)$ \\
$\begin{array}{l}\text { General assembly meetings in } \\
\text { 2004 }\end{array}$ & $3(3)$ & $5(3)$ & $4(3)$ \\
$\begin{array}{l}\text { General assembly meetings } \\
\text { attendance in 2004 (\%) }\end{array}$ & 63 & 42 & 52 \\
\hline
\end{tabular}

Figures in parenthesis are medians; $\mathrm{n}=$ the number of PMGs.

Source: PMG survey 2005

The groups had convened five (in Mbeere) to six (in Makueni) general assembly meetings since their formation. The proportion of members attending the general assembly meetings

\footnotetext{
${ }^{8}$ It is possible that non-secret ballots could be vulnerable to manipulation and rent-seeking behavior that may reduce the performance of farmer organizations (eg, Mude 2006). While most PMG leaders were elected through an open vote counting process, some of them adopted a consensus approach through acclamation. There is a need to institute proper democratic procedures that determine the period of service and allow unhindered expression of choice of leaders by the members.
} 
ranged from 42 percent in Makueni to 63 percent in Mbeere. Regarding the factor that matter most for governance and management of the PMGs, the respondents ranked several factors including the leadership quality of the office bearers and management systems in order of importance. The respondents ranked quality of the chairperson $($ median $=2)$ as most important followed by the quality of the executive committee (median $=2.5)$ while other factors like transparency in accounting, rules and norms for coordination, and rules and norms for conflict resolution, with a median of 3 , were equally ranked (Table 9).

Table 9--Mean and median ranking of factors important for PMG governance and management (where 1 = excellent)

\begin{tabular}{lccc}
\hline Attribute & Mbeere (n= 5) & Makueni (n= 5) & Total (n= 10) \\
\hline Quality of the chairperson & $2.6(2)$ & $2.2(2)$ & $2.4(2)$ \\
$\begin{array}{l}\text { Transparency in accounting } \\
\begin{array}{l}\text { Quality of the executive } \\
\text { committee }\end{array}\end{array}$ & $2.6(3)$ & $2.2(2)$ & $2.4(2.5)$ \\
$\begin{array}{l}\text { Rules and norms for coordination } \\
\begin{array}{l}\text { Rules and norms for conflict } \\
\text { resolution }\end{array}\end{array}$ & $2.8(3)$ & $2.8(3)$ & $2.9(3)$ \\
\hline
\end{tabular}

$\mathrm{n}=$ the number of PMGs.

Source: PMG survey 2005

\section{PMGs, markets and marketing channels}

The PMGs are expected to play a primary role in facilitating the integration of small producers into well functioning markets. Using data from the household survey, we analyzed the market structure in terms of transactions (number of sales and volume) by distance and market participants during 2003/2004 trade year. The results show that rural wholesalers accounted for 45 percent of transactions and 49 percent of the volume traded while 
brokers/assemblers accounted for 38 percent of the transactions and of the traded volume (Table 10). 
Table 10--Total transactions (number of sales) and volumes (tons) in 2004/05 (all crops) $(\mathrm{n}=624)$

\begin{tabular}{|c|c|c|c|c|c|c|c|c|c|c|c|c|}
\hline \multirow[t]{2}{*}{ Buyer } & \multicolumn{2}{|l|}{ Total } & \multicolumn{2}{|c|}{ Share (\%) } & \multicolumn{2}{|c|}{ Farmgate } & \multicolumn{2}{|c|}{$<3 \mathbf{k m}$} & \multicolumn{2}{|c|}{3 - 5 km } & \multicolumn{2}{|c|}{$>5 \mathrm{~km}$} \\
\hline & Sales & Volume & Sales & Volume & Sales & Volume & Sales & Volume & Sales & Volume & Sales & Volume \\
\hline Consumer & 33 & 6.5 & 5 & 3 & 21 & 4.7 & 6 & 0.7 & 3 & 0.5 & 3 & 0.7 \\
\hline PMG & 27 & 3.7 & 4 & 2 & 4 & 0.8 & 10 & 0.7 & 12 & 2.2 & 1 & 0.1 \\
\hline Rural wholesaler & 283 & 101.8 & 45 & 49 & 25 & 27.5 & 167 & 43.3 & 82 & 29.9 & 9 & 1.0 \\
\hline Broker/assemblers & 237 & 77.7 & 38 & 38 & 175 & 60.0 & 24 & 5.2 & 16 & 2.9 & 22 & 9.7 \\
\hline Urban wholesaler & 13 & 6.4 & 2 & 3 & 1 & 0.0 & 3 & 0.2 & 3 & 0.2 & 6 & 6.1 \\
\hline Cotton ginnery & 12 & 4.7 & 2 & 2 & - & - & 2 & 0.4 & 9 & 4.1 & 1 & 0.2 \\
\hline School & 19 & 4.9 & 3 & 2 & - & - & 2 & 0.7 & 10 & 2.1 & 7 & 2.0 \\
\hline Total & 624 & 205.7 & 100 & 100 & 226 & 93.0 & 214 & 51.1 & 135 & 41.9 & 49 & 19.7 \\
\hline Share $(\%)$ & & & & & 36 & 45 & 34 & 25 & 22 & 20 & 8 & 10 \\
\hline
\end{tabular}

$\mathrm{n}=$ the number of point transactions

Source: 2005 household survey 
PMGs accounted for 4 percent of the sales and 2 percent of the volume and rural consumers (ie, farmers who are deficit producers) accounted for less than 10 percent of the sales and volume purchased from farmers. The low market share of the PMGs in the marketing chain can be attributed to their inability to pay immediately after grain delivery making them less attractive to cash-constrained farmers. Schools also bought grain for the "school feeding program" that accounted for 3 percent of the transactions and 2 percent of the volume traded. The results further indicate that 45 percent of the traded volume and 36 percent of the transactions were conducted at the farmgate. It is also evident that rural wholesalers and broker/assemblers jointly control more than 80 percent of the transactions and traded volumes. This shows that these marketing channels are the easily available options to farmers in remote areas. The rural brokers/assemblers are well organized buyers with the necessary capital and mobility to buy directly from dispersed farmers. The rural wholesalers do not buy as much as brokers/assemblers at the farmgate mainly because they are less mobile and often require farmers to bring their produce to their trading points.

About 34 percent of the transactions, which accounted for 25 percent of the traded volume, were conducted within $3 \mathrm{~km}$ off farmgate. Although the transactions at the two points were not very different, the differential in traded volume is large, showing that at large distances, small volumes are transacted. This evidence attests to the fact that large distances can lead to incomplete markets as farmers attempt to economize on transportation costs, especially when prices do not increase significantly with distance to compensate for the added costs (Key et al. 2000). It is important to note that with increasing distance from the farmgate, the number of transactions and volumes traded by market participant decline. This can be attributed to the increasing transportation and transaction costs for the small quantities 
marketed and is consistent with the findings by Fafchamps and Hill (2005), which show that selling directly to markets (where farmers can get a higher price but must incur a transport cost) is more likely when the quantity sold is large and the market is close by. This further indicates a potential business opportunity for PMGs through bulk selling.

To illustrate the market transactions by different market participants in terms of prices, market shares, and also the effect of drought, we present the case of pigeonpea for 2003 and 2005 (Table 11). 
Table 11--Marketed volumes and transactions of pigeonpea and the impact of distances on sales

\begin{tabular}{|c|c|c|c|c|c|c|c|c|c|c|c|c|c|c|c|c|}
\hline \multirow[t]{3}{*}{ Buyer } & \multicolumn{2}{|c|}{$\begin{array}{l}\text { Traded volume } \\
\text { (tons) }\end{array}$} & \multicolumn{2}{|c|}{$\begin{array}{l}\text { Volume share } \\
(\%)\end{array}$} & \multirow{2}{*}{\multicolumn{2}{|c|}{$\begin{array}{l}\text { Number of } \\
\text { transactions }\end{array}$}} & \multicolumn{8}{|c|}{ Distance from farmgate } & \multirow{2}{*}{\multicolumn{2}{|c|}{$\begin{array}{l}\text { Mean price } \\
(\mathrm{Ksh} / \mathrm{kg}\end{array}$}} \\
\hline & \multirow[b]{2}{*}{2003} & \multirow[b]{2}{*}{2005} & \multirow[b]{2}{*}{2003} & \multirow[b]{2}{*}{2005} & & & \multicolumn{2}{|c|}{ Farmgate } & \multicolumn{2}{|c|}{$<3 \mathbf{k m}$} & \multicolumn{2}{|c|}{$3-5 \mathrm{~km}$} & \multicolumn{2}{|c|}{$>5 \mathrm{~km}$} & & \\
\hline & & & & & 2003 & 2005 & 2003 & 2005 & 2003 & 2005 & 2003 & 2005 & 2003 & 2005 & 2003 & 2005 \\
\hline Consumer & 2.0 & 0.36 & 5 & 8 & 23 & 3 & 20 & 0 & 2 & 1 & 1 & 2 & 0 & 0 & 22 & 25 \\
\hline PMG & - & 0.35 & - & 7 & - & 7 & - & 1 & - & 3 & - & 3 & - & 0 & & 27 \\
\hline Rural wholesaler & 11.9 & 1.65 & 24.6 & 35 & 93 & 22 & 9 & 2 & 56 & 12 & 22 & 6 & 6 & 2 & 15.3 & 23 \\
\hline Broker/assembler & 24.6 & 2.06 & 60 & 44 & 110 & 15 & 76 & 10 & 14 & 1 & 5 & 1 & 15 & 3 & 18.6 & 25 \\
\hline Urban wholesaler & 2.8 & 0.29 & 7 & 6 & 17 & 3 & 3 & 0 & 3 & 1 & 0 & 1 & 11 & 1 & 24.8 & 24 \\
\hline Total & 41.3 & 4.68 & 100 & 100 & 243 & 50 & 108 & 13 & 75 & 18 & 28 & 13 & 32 & 6 & 18.1 & 25 \\
\hline Share $(\%)$ & - & - & - & - & - & - & 44 & 26 & 31 & 36 & 12 & 26 & 13 & 12 & & \\
\hline
\end{tabular}

Source: Household survey 2003 
The results show that the drought situation that prevailed in 2004 had significantly depressed the marketed surplus and the number of transactions. ${ }^{9}$ While the number of transactions declined from 243 in 2003 to just 50 in 2005, traded volume declined from about 41 tons to 4.7 tons. This drastic change in market participation is significant given that pigeonpea is one of the most drought-tolerant crops grown in these areas. When we look at the prices offered by the different buyers, the PMG prices (Ksh 27/kg) were higher than all other agents. The prices paid by the other agents seem to be relatively similar (Ksh 2325/kg). Does this indicate that the PMGs (after having covered their marketing and administration costs) indeed pay a statistically higher price with lower variance than the other buyers?

Statistical and econometric methods were used to test these effects. An F-test using analyses of variance methods confirmed that the mean prices offered by different buyers varied significantly across buyers of maize, beans, and greengram whereas a Bartlett test for equal variance (Ho: unit price variances across buyers are equal) was rejected (at 5 percent level) for most crops other than cotton (see Appendix 2). The group variance comparison test was used to check whether the PMGs helped to reduce price instability or variability. This was done only for pigeonpea and greengram, the two crops that the PMGs bought in 2005. The null hypotheses of equal variance in the pigeonpea prices of PMGs and other buyers (rural assemblers/brokers \& rural wholesalers) were not rejected at 5 percent level. For greengram, the results show that the PMG prices seemed to have higher variability compared to prices paid by rural wholesalers. However, the null hypothesis of equal variance was not

\footnotetext{
${ }^{9}$ Meteorological data show that the average annual rainfall for Makueni (2004) was about $468 \mathrm{~mm}$, which is well below the minimum rainfall of about $650 \mathrm{~mm}$ required for agricultural production in these areas. While farmers also reported drought conditions in Mbeere in 2004, the severity seems to be lower than in Makueni.
} 
rejected when PMG greengram price was compared to that of rural assemblers/brokers. This suggests that while PMGs may offer higher mean prices to member farmers, the effect on price stabilization is unlikely to be evident in the cross-sectional data used here.

In order to test whether the average prices paid by the PMGs were statistically different after controlling for other factors, we estimated an econometric model for actual prices received by farmers. The model dependent variable was the unit price received by farmers for different crops in different markets located at varying distances from the farm (including the farmgate). The model explanatory variables included: amount sold, amount sold squared, distance to the point of sell, dummy variables for the type of crop sold (bean, pigeonpea, greengram, cowpea, cotton and vegetables), the quality of grain sold, the type of buyer (PMG, consumer, rural wholesaler, urban trader, ginnery, school), season the grain was sold, gender of household head, level of education of the household head, access to information and fixed district level effects. A detailed description of these variables is given in Table 12. 
Table 12--Description of regression model variables $\left(n=624^{*}\right)$

\begin{tabular}{|c|c|c|c|c|}
\hline Variable name & Description & Mean & Minimum & Maximum \\
\hline Price (dependent) & Unit price $(\mathrm{Ksh} / \mathrm{kg})$ & 19.24 & 6 & 50 \\
\hline Sold & Amount sold (kg) & 324.95 & 3 & 6000 \\
\hline Sold squared & Amount sold squared (1000 kg) & 439 & 0.009 & 36,000 \\
\hline Distance & Distance to sales point $(\mathrm{km})$ & 4.6 & 0 & 400 \\
\hline Maize (reference) & Maize $(1=$ maize, $0=$ otherwise $)$ & 0.46 & 0 & 1 \\
\hline Beans & Beans $(1=$ beans, $0=$ otherwise $)$ & 0.06 & 0 & 1 \\
\hline Pigeonpea & $\begin{array}{l}\text { Pigeonpea grain }(1=\text { pigeonpea grain, } \\
0=\text { otherwise })\end{array}$ & 0.08 & 0 & 1 \\
\hline Chickpea & $\begin{array}{l}\text { Chickpea }(1=\text { chickpea, } 0= \\
\text { otherwise) }\end{array}$ & 0.03 & 0 & 1 \\
\hline Greengram & $\begin{array}{l}\text { Greengram }(1=\text { greengram, } 0= \\
\text { otherwise })\end{array}$ & 0.27 & 0 & 1 \\
\hline Cowpea & Cowpea $(1=$ cowpea, $0=$ otherwise $)$ & 0.03 & 0 & 1 \\
\hline Cotton & Cotton $(1=$ cotton, $0=$ otherwise $)$ & 0.04 & 0 & 1 \\
\hline Vegetables & $\begin{array}{l}\text { Vegetables }(1=\text { vegetables, } 0= \\
\text { otherwise })\end{array}$ & 0.04 & 0 & 1 \\
\hline $\begin{array}{l}\text { Quality1 } \\
\text { (reference) }\end{array}$ & $\begin{array}{l}\text { Quality of the crop sold }(1=\text { above } \\
\text { average, } 0=\text { average })\end{array}$ & 0.08 & 0 & 1 \\
\hline Quality2 & $\begin{array}{l}\text { Quality of the crop sold }(1=\text { average, } \\
0=\text { above average })\end{array}$ & 0.92 & 0 & 1 \\
\hline District & District $(1=$ Makueni, $0=$ Mbeere $)$ & 0.16 & 0 & 1 \\
\hline District (reference) & District $(1=$ Mbeere, $0=$ Makueni) & 0.84 & 0 & 1 \\
\hline Broker (reference) & $\begin{array}{l}\text { Broker/assembler buyer }(1= \\
\text { broker/assembler, } 0=\text { otherwise })\end{array}$ & 0.38 & 0 & 1 \\
\hline Consumer & $\begin{array}{l}\text { Consumer buyer }(1=\text { consumer, } 0= \\
\text { otherwise })\end{array}$ & 0.05 & 0 & 1 \\
\hline PMG & PMG buyer ( $1=$ PMG, $0=$ otherwise) & 0.04 & 0 & 1 \\
\hline Rural wholesaler & $\begin{array}{l}\text { Rural wholesaler buyer }(1=\text { Rural } \\
\text { wholesaler, } 0=\text { otherwise })\end{array}$ & 0.45 & 0 & 1 \\
\hline Urban trader & $\begin{array}{l}\text { Urban trader buyer }(1=\text { urban trader, } \\
0=\text { otherwise })\end{array}$ & 0.02 & 0 & 1 \\
\hline Cotton ginnery & $\begin{array}{l}\text { Cotton ginnery buyer }(1=\text { cotton } \\
\text { ginnery, } 0=\text { otherwise })\end{array}$ & 0.02 & 0 & 1 \\
\hline School & $\begin{array}{l}\text { School buyer }(1=\text { schools, } 0= \\
\text { otherwise })\end{array}$ & 0.03 & 0 & 1 \\
\hline
\end{tabular}


Table 12--Description of regression model variables $\left(n=624^{*}\right)$ (continued)

\begin{tabular}{|c|c|c|c|c|}
\hline Season 1 & $\begin{array}{l}\text { Harvest season }(1=\text { harvest, } 0= \\
\text { otherwise })\end{array}$ & 0.71 & 0 & 1 \\
\hline Season2 & $\begin{array}{l}\text { Some } 2-3 \text { months after harvest }(\text { Yes }= \\
1,0=0 \text { therwise })\end{array}$ & 0.19 & 0 & 1 \\
\hline Season3 (reference) & $\begin{array}{l}\text { Some } 4-5 \text { months after harvest }(\text { Yes }= \\
1,0=\text { otherwise })\end{array}$ & 0.11 & 0 & 1 \\
\hline Gender & $\begin{array}{l}\text { Gender of household head }(1=\text { Male, } \\
0=\text { Female })\end{array}$ & 0.84 & 0 & 1 \\
\hline Education & Education of household head (Years) & 6.79 & 0 & 14 \\
\hline Own ICT & $\begin{array}{l}\text { Household owns } \operatorname{ICT}^{\#}(1=\text { Yes, } 0= \\
\text { No) }\end{array}$ & 0.82 & 0 & 1 \\
\hline
\end{tabular}

$*_{n}=624$ is the number of point transactions;

${ }^{\#}$ ICT means Information and Communication Technology assets (eg, radio, television and mobile phone). Source: Household survey 2005

The estimated model was significant $(\mathrm{P}<0.001)$ and explained about 61 percent of the variation $\left(\mathrm{R}^{2}=0.612\right)$. The model results show that farmer grain prices are significantly determined by the distance to the point of transaction, the type of crop sold, location by district, buyer type (particularly consumers, PMGs and schools) and the season the grain is sold. Unit prices were positively correlated with distance (Table 13). 
Table 13--Determinants of grain prices received by farmers

\begin{tabular}{|c|c|c|c|c|}
\hline Variable & Coefficient & Std. Err. & t-value & $\mathbf{P}>|\mathbf{t}|$ \\
\hline Sold & -0.001 & 0.001 & -0.97 & 0.334 \\
\hline Sold squared & $3.34 \times 10^{-8}$ & $2.13 \times 10^{-7}$ & 0.16 & 0.875 \\
\hline Distance & 0.023 & 0.012 & 1.97 & 0.050 \\
\hline Beans & 15.163 & 1.011 & 14.99 & 0.000 \\
\hline Pigeonpea & 11.275 & 0.935 & 12.06 & 0.000 \\
\hline Chickpea & 13.512 & 1.452 & 9.31 & 0.000 \\
\hline Greengram & 12.321 & 0.634 & 19.45 & 0.000 \\
\hline Cowpea & 4.061 & 1.359 & 2.99 & 0.003 \\
\hline Cotton & 7.760 & 1.625 & 4.77 & 0.000 \\
\hline Vegetables & 7.421 & 1.347 & 5.51 & 0.000 \\
\hline Quality & 0.222 & 0.865 & 0.26 & 0.797 \\
\hline District & -2.194 & 0.739 & -2.97 & 0.003 \\
\hline Consumer & 6.757 & 1.123 & 6.02 & 0.000 \\
\hline PMG & 5.950 & 1.180 & 5.04 & 0.000 \\
\hline Rural wholesaler & -0.614 & 0.513 & -1.20 & 0.232 \\
\hline Urban trader & 0.988 & 1.884 & 0.52 & 0.600 \\
\hline Cotton ginnery & 1.017 & 2.093 & 0.49 & 0.627 \\
\hline School & 3.570 & 1.341 & 2.66 & 0.008 \\
\hline Season 1 & -1.491 & 0.762 & -1.96 & 0.051 \\
\hline Season2 & -1.173 & 0.884 & -1.33 & 0.185 \\
\hline Gender & 0.553 & 0.680 & 0.81 & 0.417 \\
\hline Education & -0.032 & 0.066 & -0.49 & 0.622 \\
\hline Own ICT & 0.056 & 0.650 & 0.09 & 0.932 \\
\hline Constant & 13.914 & 1.421 & 9.79 & 0.000 \\
\hline $\mathrm{N}$ & 624 & & & \\
\hline$F(23,600)$ & 41.09 & & & \\
\hline $\mathrm{R}^{2}$ & 0.612 & & & \\
\hline
\end{tabular}

Reference variables include: crop price $=$ maize; quality $=$ above average; District $=$ Mbeere district; buyer $=$ broker/assembler; season $=4-5$ months after harvest.

Source: Household survey 2005 
Specifically, prices seem to increase by about Ksh 0.2 for every $10 \mathrm{~km}$ traveled from the farmgate $(\mathrm{P}<0.1)$. The effect of distance is interesting: while prices seem to increase as distance increases, the price change for the range of distances covered in this study (less than $10 \mathrm{~km}$ ) does not seem to be significant enough to create incentives for small producers to travel long distances for grain marketing. The small price gain is likely to be muted by the associated transportation costs unless the quantity sold is large enough to exploit economies of scale. This seems to explain why most farmers prefer to sell the grain at the farmgate (Tables 10 and 11). After controlling for the crop type, season, quality and type of buyer, amount sold does not seem to have a significant effect on prices received by farmers. While price and volume sold seem to be negatively correlated the relationship is not significant. This indicates that smallholders are price takers and volumes from individual farmers are too small to influence market prices.

The prices vary significantly across crops $(\mathrm{P}<0.01)$. In relation to maize (reference crop) the price variation ranges from Ksh 4/kg for cowpea (Cowpea) to about Ksh 15/kg for beans (Beans). Pigeonpea and greengram - two predominant cash crops in the study districts - sell at Ksh 12 over and above the price for maize while chickpea fetches about Ksh 14/kg more than maize. An interesting result is that grain quality does not seem to matter in price determination (the price differential between above average quality and average quality grain is insignificant). This is a reflection of the classic case of asymmetric information (Akerlof 1970) where buyers take the quality of a good to be uncertain and consider only average quality of a good with the implication that suppliers of superior produce will be driven out of the market. 
Indicating some differences in price across districts, farmers in Makueni district receive Ksh $2 / \mathrm{kg}$ less than those in the (reference) Mbeere district $(\mathrm{P}<0.01)$. This may be due to the relative proximity of Mbeere district to Nairobi - a major urban market for agricultural produce across the country (Table 2). When we look at the different marketing channels, consumers, PMGs and schools respectively paid about Ksh 7, Ksh 6, and about Ksh 4 over and above the prices paid by brokers/assemblers $(\mathrm{P}<0.01)$. The buying prices of rural wholesalers, urban traders and cotton ginneries are not significantly different from those paid by the brokers. This shows that PMGs can be attractive market outlets for small producers especially if they can resolve certain marketing constraints. The school feeding programs (captured by the school variable) also seem to provide an alternative market outlet for farmers at prices significantly higher than brokers $(\mathrm{P}<0.01)$.

Controlling for crop type, market outlet distances, location, and the type of grain buyer, farmers selling their produce at harvest (Season1) would lose about Ksh 1.5/kg compared to those who can afford to delay selling for 4-5 months (reference season) after harvest $(\mathrm{P}<0.1)$. However, the price differential for a 2-3 months delay after harvest (Season2) is not significantly different from a 4-5 months delay. This implies that storing grain would be beneficial to the farmers especially if the incremental price would offset the storage costs including potential weight loss and pest attack. This shows that PMGs can exploit the seasonal price variability by facilitating storage and bulk sales (to reduce unit storage costs) so that farmers can benefit from better prices later in the season.

\section{PMGs and price determination}

Various factors may affect the buying and selling prices of a product differently depending on how the buyer or seller ranks the factors on a given scale. With respect to 
PMGs, the prices they offer will determine their attractiveness to members as a market outlet for their produce. Using group data, the mean and median rankings of factors considered in setting buying and selling prices of the PMGs were analyzed.

The results show that prices offered by other traders (rank 2), season (rank 3), prevailing prices in Nairobi and other urban centers (3.5), and product quality (rank 4) are the most important factors that the PMGs take into account in determining grain buying prices (Table 14).

Table 14--Rankings of determinants of buying and selling prices (where $1=$ most important).

\begin{tabular}{lllllll}
\hline Factor & \multicolumn{2}{l}{ Mbeere $(\mathbf{n}=\mathbf{5})$} & \multicolumn{2}{l}{ Makueni $(\mathbf{n}=\mathbf{5})$} & \multicolumn{2}{l}{ Total $(\mathbf{n}=\mathbf{1 0})$} \\
\cline { 2 - 7 } & Buying & selling & Buying & Selling & Buying & Selling \\
\hline $\begin{array}{l}\text { Price in Nairobi and/or } \\
\text { other urban areas }\end{array}$ & $5.6(5)$ & $2(1)$ & $2(1)$ & $1.4(1)$ & $3.8(3.5)$ & $1.7(1)$ \\
Price offered by traders & $4(2)$ & $2.6(2)$ & $2(2)$ & $2.8(2)$ & $1.8(2)$ & $3(2)$ \\
Product quality & $4.8(4)$ & $3.6(3)$ & $4.2(4)$ & $3.4(3)$ & $4.5(4)$ & $3.5(3)$ \\
Season & $6.6(5)$ & $5.2(5)$ & $2.2(3)$ & $2.8(3)$ & $4.1(3)$ & $4(4)$ \\
Prices asked by farmers & $6(6)$ & $4(4)$ & $5.4(5)$ & $4.8(5)$ & $5.7(5.5)$ & $4.4(5)$ \\
Previous year price & $7(6)$ & $6(6.5)$ & $5.2(6)$ & $5.8(6)$ & $5.7(6)$ & $5.7(6)$ \\
Production cost & $5.4(6)$ & $4.8(5)$ & $8(8)$ & $8(8)$ & $6.7(8)$ & $6.4(8)$ \\
Transport cost & $8(8)$ & $7.8(8)$ & $8(8)$ & $8(8)$ & $8(8)$ & $7.9(8)$ \\
\hline
\end{tabular}

Figures in parentheses are medians; $\mathrm{n}=$ number of PMGs.

Source: PMG survey 2005

However, prices in Nairobi and other urban areas (rank 1), prices offered by other traders (rank 2), product quality (rank 3) and season (rank 4) are important in determining the selling prices of PMGs. The importance of urban centers in determining PMGs prices suggests some degree of grain market co-integration between the rural and urban markets. Furthermore, the end users of the products in the marketing chain are generally located in the urban areas.

Farmer production costs are not highly ranked in determining PMG buying or selling prices. This means that PMGs are grain price takers rather than price setters. Interestingly, the ranks 
seem to indicate that quality is more important during selling rather than buying the products. The econometric analysis results presented in Table 13 have confirmed that quality did not affect prices received by farmers.

Although there is no price premium for quality, PMGs consider certain grain quality attributes when buying from members. These attributes include pest attack, moisture content, foreign matter, grain color, among others. These factors reflect the quality of the produce that is desired by the PMGs. The median rankings show that pest attack (1), percentage of foreign matter in the grain (2.5), moisture content (3.5), grain size (3.5), and grain color (4.5) are important attributes (Table 15).

Table 15--Mean and median rankings of pigeonpea quality attributes (where $1=$ most important).

\begin{tabular}{llll}
\hline Attribute & Mbeere $(\mathbf{n}=\mathbf{5})$ & Makueni $(\mathbf{n}=\mathbf{5})$ & Total $(\mathbf{n}=\mathbf{1 0})$ \\
\hline Pest attack & $2.4(2)$ & $1.8(1)$ & $1.8(1)$ \\
Foreign matter & $3.4(4)$ & $2.2(2)$ & $2.8(2.5)$ \\
Moisture content & $3.8(4)$ & $3.4(3)$ & $3.6(3.5)$ \\
Grain size & $3.6(5)$ & $3.4(4)$ & $3.5(4)$ \\
Grain color & $3.6(3)$ & $4.8(5)$ & $4.2(4.5)$ \\
Smell & $6.6(6)$ & $6(6)$ & $6.3(6)$ \\
Field pests & $5(7)$ & $7(7)$ & $6(7)$ \\
Mixed varieties & $6.6(7)$ & $7(7)$ & $6.8(7)$ \\
\hline
\end{tabular}

Values in parentheses are medians; $\mathrm{n}=$ number of PMGs.

Source: PMG survey 2005

This is likely to affect the supply of quality and differentiated products by small farmers as they lack the incentives in a market where prices reflect fair average quality and there is no premium for superior quality products.

When PMGs coordinate marketing functions, they need to cover the associated administration and other transaction costs. Assembling, bulking, storage and marketing 
functions and the associated costs need to be explicitly considered in determining the final price paid to farmers. For example, depending on the duration of storage, the grain could lose weight through moisture loss, and hence the total quantity sold. The results show that farmers who sold through the PMGs received, on average, between 90-95 percent of the PMG selling price (Table 16).

Table 16--Average PMG selling price and farmers' final price (2003 and 2004)

\begin{tabular}{llll} 
Crop & $\begin{array}{l}\text { PMG selling price } \\
\text { (Ksh/kg) }\end{array}$ & $\begin{array}{l}\text { Farmers' final } \\
\text { price (Ksh/kg) }\end{array}$ & $\begin{array}{l}\text { Farmer price (\% of } \\
\text { PMG price) }\end{array}$ \\
\hline Maize & 18 & 16 & 89 \\
Dry pigeonpea grain & 22 & 21 & 93 \\
Green pigeonpea & 14 & 13 & 90 \\
Beans & 40 & 20 & 50 \\
Greengram & 25 & 24 & 94 \\
Kabuli chickpea & 40 & 38 & 95 \\
Desi chickpea & 20 & 18 & 90 \\
\hline
\end{tabular}

Source: PMG survey 2005

The balance was used by the PMGs to cover costs incurred in coordinating sales including transportation costs. This indicates a high level of efficiency by the PMGs in their marketing functions.

Another critical factor that determines the choice of marketing channels by farmers is the time lag between delivery and receipt of payments for the delivered product. The delay in payments among different buyers after grain delivery varied between instantaneous and five weeks (Table 17). 
Table 17--Number of weeks taken for payment after sale by market participants

\begin{tabular}{lll} 
Buyer & Mean & Number of transactions \\
\hline Broker/assemblers & 0.0 & 237 \\
School & 0.0 & 19 \\
Rural wholesaler & 0.1 & 283 \\
Consumer & 0.1 & 33 \\
Urban trader & 0.1 & 13 \\
Cotton ginnery & 1.2 & 12 \\
PMG & 5.0 & 27 \\
Total & 0.3 & 624
\end{tabular}

Source: Household survey 2005

Brokers/assemblers and schools paid on delivery, while rural wholesalers, urban traders and the cotton ginnery paid about a day after delivery. In contrast, it took the PMGs five weeks to pay farmers after they had delivered their grain. Many cash-constrained farmers who need cash to settle various commitments (eg, loans, schools fees and other necessities) at the time of delivery often opt to sell their grain through other channels even if this means relatively lower prices. One useful strategy for the PMGs to increase their market share would require that they pay farmers at least a certain proportion of the grain value at the time of delivery pending full payments after selling the grain at a higher price later.

\section{Collective action and PMG performance}

One major difficulty in collective action studies is to measure the level of collective action and how such group action contributes to final performance outcomes. Generally there are no standardized measures or indicators that can be used to assess the level, viability and effectiveness (performance) of collective action (eg, Place et al. 2002). However, depending on the problem under investigation, certain indicators may be identified as proxies for the differential level of collective action (those that capture the level of cooperation or group action) and the degree of effectiveness of such collective action in attaining a group's stated 
objectives. This kind of separation allows us to assess the extent to which collective action can be attributed to good performance in terms of final outcomes. Accordingly we use a qualitative approach based on an in-depth study of the PMG operations to identify some indicators for the levels of collective action and its effectiveness (performance).

The level of collective action across groups can be inferred by commitment attributes of the individual members to the group activities and objectives. These may include the extent to which individual members relate with other members of the group within the confines of the existing institutional mechanisms and governance structures, and commitment or subscription to the group's ideals or the extent to which the individual members share a common vision. Accordingly, six indicators of collective action were identified: the number of elections since formation, share of members respecting the bylaws, attendance of meetings, annual member contributions to the group, cash capital and agreed annual subscription fees. In order to facilitate comparison across groups, the indicators were standardized in per capita or in percentage values.

The results using these indicators show that the level of collective action varied across PMGs (Table 18). 
Table 18--Selected indicators for the level of collective action by PMGs

\begin{tabular}{|c|c|c|c|c|c|c|}
\hline PMG & $\begin{array}{l}\text { Average annual } \\
\text { elections since } \\
\text { formation }\end{array}$ & $\begin{array}{l}\% \text { of members } \\
\text { respecting by-laws }\end{array}$ & $\begin{array}{l}\text { Member attendance of } \\
\text { general meetings in } 2004 \\
(\%)\end{array}$ & $\begin{array}{l}\text { Member } \\
\text { contribution in } 2004 \\
\text { (Ksh/active member }\end{array}$ & $\begin{array}{l}\text { Per capita capital } \\
\text { in } 2005(\mathrm{Ksh} / \\
\text { member })\end{array}$ & $\begin{array}{l}\text { Annual } \\
\text { subscription fee } \\
\text { (Ksh/ member) }\end{array}$ \\
\hline Wango & 1 & 75 & 65 & 0 & 63 & 120 \\
\hline Nthingini & 0.5 & 65 & 57 & 21 & 34 & 20 \\
\hline Kilia & 1 & 70 & 76 & 0 & 0 & 0 \\
\hline Kamwiyendeyi & 0.5 & 80 & 85 & 0 & 0 & 0 \\
\hline Makima & 2 & 100 & 48 & 160 & 123 & 1800 \\
\hline Emali & 1 & 100 & 61 & 0 & 43 & 240 \\
\hline Thavu & 1 & 90 & 95 & 0 & 43 & 0 \\
\hline Kathonzweni & 1 & 67 & 67 & 264 & 265 & 120 \\
\hline Kalamba & 1 & 71 & 64 & 247 & 319 & 360 \\
\hline KYM & 1 & 50 & 46 & 2 & 180 & 0 \\
\hline
\end{tabular}

Source: PMG survey 2005 
Elections are a means through which members can ensure that groups are managed effectively. They are an indication that members are actively participating in group decisions which are monitored and enforced collectively (McCarthy et al. 2002), which is a good measure of the level of collective action. The groups conducted an election annually although in two groups (Nthingini and Kamwiyendeyi), elections were conducted after two years, whereas Makima conducted elections biannually (indicating a higher level of collective action).

By-laws define the obligation and the mode of interaction between members and the PMG leadership for the smooth and effective running of the groups in the process of pursuing the groups' objectives. Abiding by the laws also reduces governance and coordination costs. The proportion of members who respect group by-laws ranged between 50 and 100 percent. Half the PMGs reported that upwards of 75 percent of the members adhered to the by-laws. PMGs like Makima, Emali and Thavu had higher values on this indicator. A related indicator is the proportion of members attending general assembly meetings where important resolutions are passed. It shows the level of involvement by individuals in the management and coordination of collective action. The proportion of members who attended the general assembly meetings was 46-95 percent, with 60 percent of the PMGs reporting less than 65 percent attendance. The good performers in this indicator include Thavu, Kamyendeyi and Kathonzweni.

Annual subscriptions can be used by PMGs to overcome working capital constraints in the course of their operations. Member contributions are usually aimed at pooling resources for implementing a group project where members have a common interest. Hence, the amount of annual subscriptions is a good indicator that shows commitment on the part of 
the members towards the PMG objectives. Accordingly annual subscriptions varied across the groups and were between Ksh 0-1800. High annual subscriptions are likely to lead to higher capital investments by PMGs over time. ${ }^{10}$ The per capita contributions in 2004 ranged between Ksh 0 and 264. The per capita operating capital held in 2005 ranged between Ksh 0319. Groups like Makima, Kathonzweni and Kalamba performed best on these indicators.

Based on the selected six indicators for the level of collective action, the PMGs were ranked $(1=$ most successful $)$ according to the values of each indicator to identify those that are relatively more successful in collective action, and also to identify the factors that contribute to good performance. A simple average rank was then computed across the six indicators. Since we have assumed equal weights for these indicators for simplicity, the PMGs below the average rank of 5 may be considered relatively more successful in collective action. The mean rankings show that Kalamba (3.0), Makima (3.2), Kathonzweni (4.3) and Wango (4.8) were more successful than the rest (Table 19).

\footnotetext{
${ }^{10}$ High subscription or membership fees may also lead to exclusion of the poor with potentially negative distributive impacts for marginal and vulnerable groups.
} 
Table 19--Rankings of PMGs based on level of Collection Action (CA) indicators (where $1=$ highest CA)

\begin{tabular}{|c|c|c|c|c|c|c|c|}
\hline PMG & $\begin{array}{l}\text { Average annual } \\
\text { elections since } \\
\text { formation }\end{array}$ & $\begin{array}{l}\% \text { of members } \\
\text { respecting by- } \\
\text { laws }\end{array}$ & $\begin{array}{l}\text { Member attendance of } \\
\text { general meetings in } \\
2004(\%)\end{array}$ & $\begin{array}{l}\text { Member } \\
\text { contributions in } \\
2004 \text { (Ksh/active } \\
\text { member }\end{array}$ & $\begin{array}{l}\text { Per capita } \\
\text { capital in } 2005 \\
\text { (Ksh/ member) }\end{array}$ & $\begin{array}{l}\text { Annual } \\
\text { subscription fee } \\
\text { (Ksh/member) }\end{array}$ & Mean rank \\
\hline Kalamba & 2 & 5 & 6 & 2 & 1 & 2 & 3.0 \\
\hline Makima & 1 & 1 & 9 & 3 & 4 & 1 & 3.2 \\
\hline Kathonzweni & 2 & 7 & 4 & 1 & 2 & 10 & 4.3 \\
\hline Wango & 2 & 4 & 5 & 10 & 5 & 3 & 4.8 \\
\hline Thavu & 2 & 2 & 1 & 10 & 6 & 10 & 5.2 \\
\hline Nthingini & 3 & 8 & 8 & 4 & 7 & 4 & 5.7 \\
\hline Emali & 2 & 1 & 7 & 10 & 6 & 10 & 6.0 \\
\hline Kamwiyendeyi & 3 & 3 & 2 & 10 & 10 & 10 & 6.3 \\
\hline KYM & 2 & 9 & 10 & 5 & 3 & 10 & 6.5 \\
\hline Kilia & 2 & 6 & 3 & 10 & 10 & 10 & 6.8 \\
\hline
\end{tabular}

Based on data in Table 18 
Kilia with a ranking of 6.8 was the least successful in terms of the level of collective action. This shows that despite its simplicity, the average ranks indeed selected the PMGs that did well in more than two or three of the collective action indicators.

To get insights on whether high levels of collective action lead to high level of performance in collective outcomes, the PMGs were compared on the basis of two outcome indicators: total assets built over time and total volume of grains traded (both standardized per member). The distribution of the levels of these indicators across PMGs show that per capita assets were lowest in Nthingini (Ksh 34) and highest in Kathonzweni (about Ksh 6393) while the per capita total sales for the 2003/04 ranged between a low of $3 \mathrm{~kg}$ in Thavu and $242 \mathrm{~kg}$ in Kathonzweni (Table 20).

Table 20--Selected indicators of performance of collective action

\begin{tabular}{lllll}
\hline PMG & $\begin{array}{l}\text { Per capita assets } \\
\text { built over time } \\
\text { (Ksh/member) }\end{array}$ & $\begin{array}{l}\text { Per capita sales volume } \\
\text { (kg/member) }\end{array}$ & $\begin{array}{l}\text { Per capita total sales } \\
\text { volume (kg/member) }\end{array}$ \\
\cline { 3 - 5 } & 63 & - & $\mathbf{2 0 0 3}$ & $\mathbf{2 0 0 4}$ \\
\hline Wango & 34 & - & 7 & 8 \\
Nthingini & 177 & 34 & 23 & 7 \\
Kilia & 333 & 192 & 0 & 57 \\
Kamwiyendeyi & 301 & - & 123 & 192 \\
Makima & 268 & 92 & 0 & 123 \\
Emali & 395 & 3 & 0 & 92 \\
Thavu & 6393 & 212 & 30 & 3 \\
Kathonzweni & 3130 & 46 & 8 & 242 \\
Kalamba & 335 & 10 & 0 & 54 \\
KYM & & & & 10 \\
\hline
\end{tabular}

* Missing data indicates that PMGs were established later in 2003 and did not sell during that year. Source: PMG survey 2005

When the sales are disaggregated by year, it becomes evident that some PMGs did not trade in one year or another while some traded in both years. As consistency in grain 
marketing is a good indicator of performance, the volume of trade is separately ranked for the two years. The aggregate rankings across the three indicators (ie, combining assets built over time and crop sales per capita) show that Kathonzweni (1.3), Kalamba (3.3) and Makima (3.5) have performed much better than PMGs like Emali, Thavu, KYM (6.7) and Nthingini (7.5) (Table 21).

Table 21--Rankings of PMGs based on performance indicators (where 1 = most successful)

\begin{tabular}{llllll} 
PMG & $\begin{array}{l}\text { Per capita } \\
\text { asset built } \\
\text { over time }\end{array}$ & $\begin{array}{l}\text { Per capita } \\
\text { sales (2003) }\end{array}$ & $\begin{array}{l}\text { Per capita } \\
\text { sales (2004) }\end{array}$ & Mean & \\
\cline { 5 - 6 } & & & & $\begin{array}{l}\text { Per capita } \\
\text { crop sales }\end{array}$ & Aggregate \\
\hline Kathonzweni & 1 & 1 & 2 & 1.5 & 1.3 \\
Kalamba & 2 & 4 & 4 & 4.0 & 3.3 \\
Makima & 6 & $-*$ & 1 & 1.0 & 3.5 \\
Kilia & 8 & 5 & 3 & 4.0 & 5.3 \\
Kamwiyendeyi & 4 & 2 & 10 & 6.0 & 5.3 \\
Wango & 9 & - & 4 & 4.0 & 6.5 \\
Emali & 7 & 3 & 10 & 6.5 & 6.7 \\
Thavu & 3 & 7 & 10 & 8.5 & 6.7 \\
KYM & 4 & 6 & 10 & 8.0 & 6.7 \\
Nthingini & 10 & - & 5 & 5.0 & 7.5 \\
\hline
\end{tabular}

* Missing data indicates that PMGs were established later in 2003 and did not sell during that year. Source: PMG survey 2005

Qualitative discussions and frequent observations during the field survey also identified these three PMGs as the best performers both in terms of the level of collective action and the marketing functions.

Assuming that performance is a function of the level of collective action and other factors (eg, distance to markets), a simple graphical analysis of the drivers of performance 
(both positive and negative) was undertaken. The results show that the number of elections held, initial start-up capital and membership fees are important positive correlates with PMG performance (Figure 4).

\section{Figure 4--Some drivers of PMG performance.}

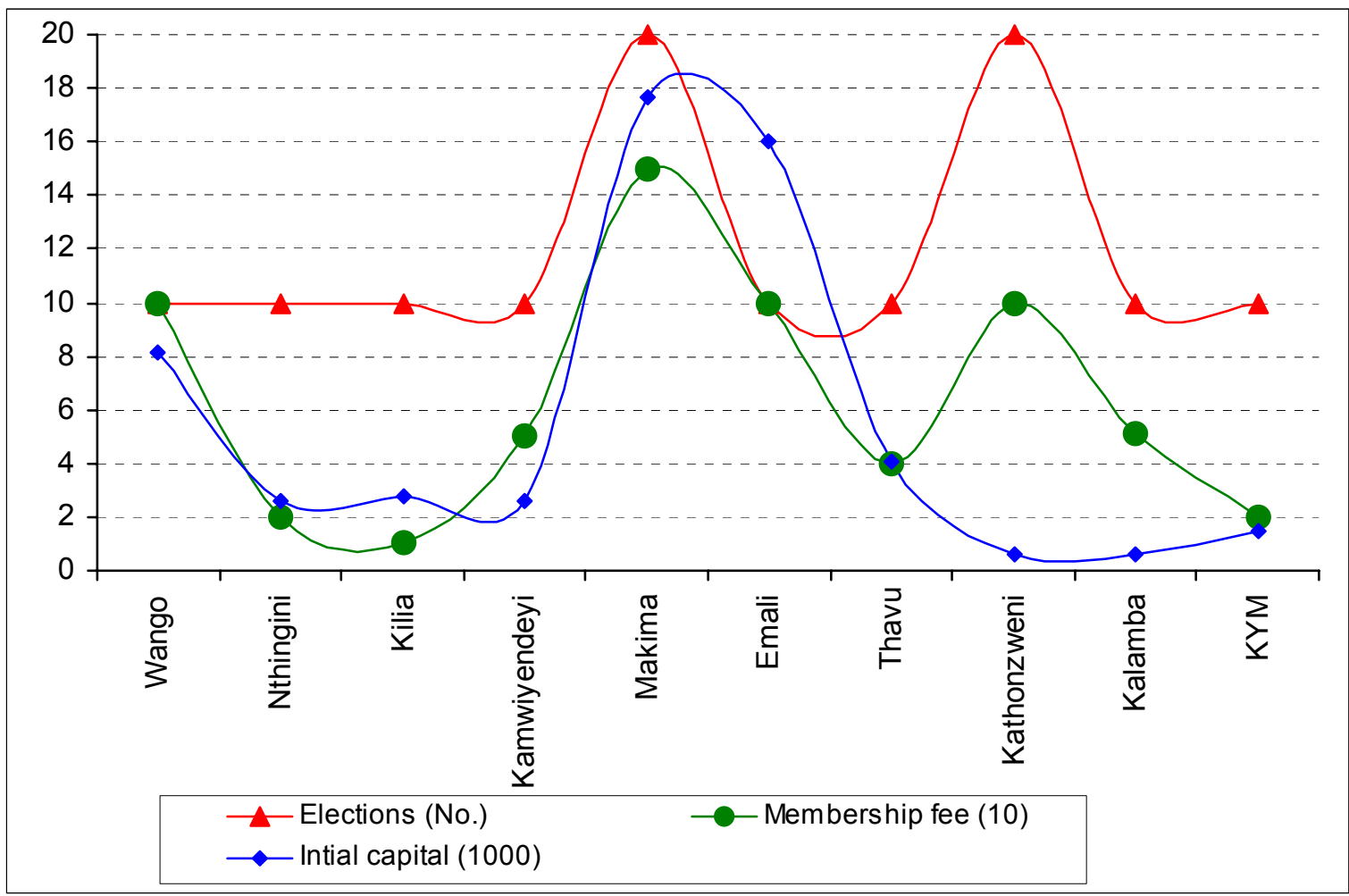

Source: PMG survey 2005

Corollary to the effects of positive drivers, the number of villages covered by the PMG, distance to markets (grain wholesalers and district commercial centers), and group size seem to be negatively associated with the effectiveness of marketing functions of the PMGs (Figure 5). 
Figure 5--Negative correlates with PMG performance.

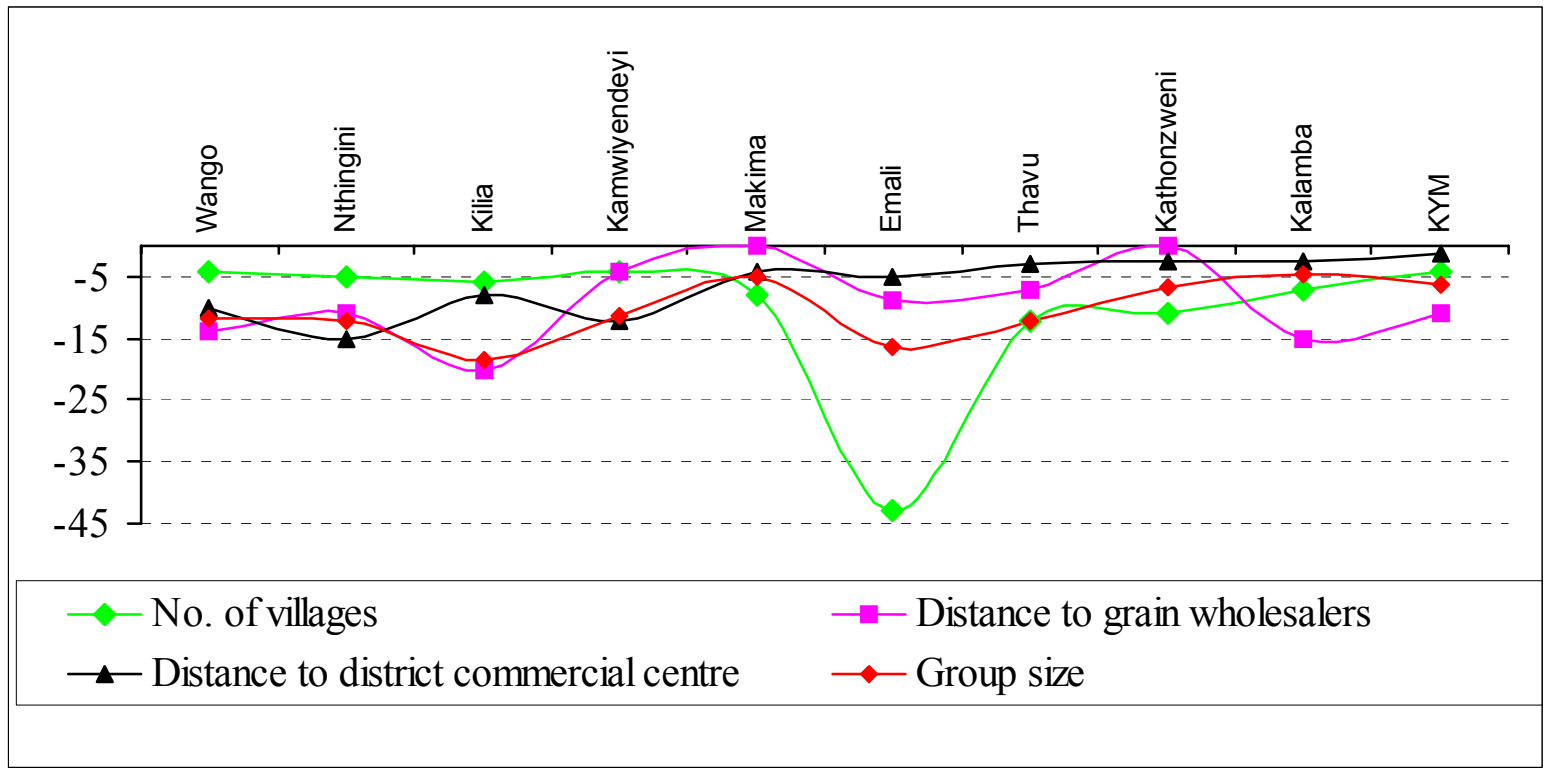

Source: PMG survey 2005

The number of villages covered by a PMG is highest for Emali, but relatively smaller for Makima, Kathonzweni and Kalamba, the more successful PMGs. The distance to wholesalers is shortest for Makima and Kathonzweni, located close to rural market centers, but higher for Nthingini, Kalamba, Kilia and KYM. The poorly-performing PMGs, Nthingini, Kamwiyendei and Wango, are also located far from the district commercial center. Moreover, the better performing PMGs like Makima, Kathonzweni, and Kalamba had relatively smaller group sizes compared to poor performers, Kilia, Nthingini and Emali. Consistent with the findings reported by McCarthy et al. (2002), group performance seemed to decline with increase in distance to markets. These results indicate that proximity to markets is likely to improve marketing functions and competitive behavior through better access to market information that would help PMGs make informed decisions on buying and selling prices, and better advertise their stock to wholesalers or other agents. It also shows that shorter 
distance to service centers and buyers at the end of the marketing chain is likely to enhance the degree of complementarity between PMGs and private enterprises.

Although group size has been shown to be positively correlated to performance (Place et al. 2002), the qualitative evidence provided here shows that this may not necessarily be the case. Effective group size is likely to vary by the type of collective action. In addition, group size may have a non-linear relationship with performance which would suggests that medium sized groups are more likely to succeed than very small groups or very large groups (Agrawal and Goyal 2001), depending on transaction, organizational and managerial costs of cooperation (Hussi et al. 1993). An optimal group size will be one that minimizes these costs, and improves the coordination of production and marketing functions. The challenge for the PMGs would be how to determine the effective group size that would be big enough to exploit economies of scale, without leading to coordination failure and prevalence of conflicts. Generally, the negative correlates jointly constrain coordination of production and the marketing functions of the PMGs. Long distance implies geographical isolation, while group size and the number of villages covered by a single PMG could be associated with higher transaction costs, coordination failure and lack of cohesion or shared goals and values.

\section{Constraints to collective marketing}

For the PMGs to be effective and successful in their collective marketing functions, constraints to their operations will have to be addressed. The median rank for the three most important constraints to collective marketing was given as: lack of credit (1), price variability (3) and low volumes (3) (Table 22). 
Table 22--Rankings of PMG collective marketing constraints (where $1=$ most important)

\begin{tabular}{lccc}
\hline Constraint & Mbeere (n= 5) & Makueni (n= 5) & Total (n= 10) \\
\hline Lack of credit & $1.4(1)$ & $1.2(1)$ & $1.3(1)$ \\
Price variability & $4.6(5)$ & $2.6(2)$ & $3.6(3)$ \\
Low volumes & $4.8(3)$ & $3.2(3)$ & $4.0(3)$ \\
Lack of buyers & $5.4(4)$ & $4.0(4)$ & $4.7(4)$ \\
Low business skills & $4.8(6)$ & $6.0(6)$ & $5.4(6)$ \\
Low quality & $7.2(7)$ & $6.2(6)$ & $6.7(7)$ \\
Storage pests & $7.6(8)$ & $7.6(7)$ & $7.6(7.5)$ \\
Internal conflicts & $8.0(8)$ & $8.2(8)$ & $8.1(8)$ \\
Poor leadership & $7.8(9)$ & $9.6(10)$ & $8.7(9)$ \\
Lack of storage & $11.3(12)$ & $8.2(7)$ & $9.4(10)$ \\
Theft in storage & $10.8(11)$ & $11.2(12)$ & $11.0(11)$ \\
\hline
\end{tabular}

Figures in parentheses are medians; and $\mathrm{n}=$ number of PMGs.

Source: PMG survey 2005

In addition, lack of buyers (4) and low business skills (6) appear to be relatively important. The prominence of lack of credit as a major constraint to collective marketing is consistent with the wide recognition that this service can play an important role for marketing and enterprise development (eg, Bingen et al. 1993; Kirkpatrick and Maimbo 2002) and for remedying market imperfections associated with risk and imperfect information (eg, Poulton et al. 1998; Kelly et al. 2003). Nonetheless, there are three approaches through which constrained access to credit by PMGs can be addressed, namely: rural micro-credit facilities, contract or outgrower schemes, and inventory credit (see Kindness and Gordon 2001).

Micro-credit schemes are a response to market failure in conventional banking services for the rural poor. They are associated with group lending since individual farmers rarely have bankable assets that can be used as collateral against formal loans. In addition, 
individual market transactions are largely informal such that formal banks are unable to collect information on prices independently. But peer pressure can effectively substitute for collateral, as group members are likely to take action to prevent a fellow member from defaulting. With a lead model demonstrated by the Grameen bank in Bangladesh, there are now several successful examples across Africa (eg, K-Rep Bank in Kenya). The disadvantage of such schemes is that their operations are normally subsidized such that the sustainability of their operations is not guaranteed in the long term. In addition, the size of loans may be small to provide capital required for grain marketing. Selective subsidies may, however, be needed to 'kick-start' agricultural markets as they play an important role in relieving critical seasonal and cash constraints, and reducing market and input supply uncertainties (Dorward et al. 2004a).

In relation to contract or outgrower schemes, processors or exporters can provide financial resources to farmers, with the latter undertaking to supply grain under conditions specified in advance (futures) contracts that often specify volumes, prices and time. Farmer organizations and PMGs can play a vital role in facilitating such contractual arrangements with the private sector in a manner that would be mutually beneficial to farmers and contractors: farmers will be able to sell their produce through the PMGs knowing that they will be paid promptly; the PMGs will be able to access capital from the private sector that would improve the viability of their business; and the processor will be guaranteed timely supply of required quantity and quality of grain. The viability of such an arrangement would depend on three factors: i) how PMGs operate as a business, ii) the extent to which they would be able to produce quality products in the desired quantity and time, and iii) the legal and institutional framework for contract formation and enforcement. The latter is critical as 
many contract farming arrangements suffer from non-binding contracts and lack of arbitration and enforcement mechanisms.

An inventory credit (also called warehouse credit) system is another option for providing credit services to PMGs. There are three players involved in this arrangement: the farmer, the PMG and a bank. The warehouse, which can also be operated by a PMG or a third party, can be used to store grain supplied by farmers with a formal bank lending a certain percentage of the grain value at the time of harvest. The PMG can use the loan to pay the farmers as well as acquire additional stocks with a plan to repay the loan later after selling the grain at higher prices during the low supply season. This option could be particularly attractive as the logistics are relatively simple and it is widely practiced in Africa. However, the success of such an arrangement will depend on the requisite institutional mechanisms which include the willingness of the banks to lend against inventories, warehouse systems that can operate within the necessary legal framework, and supportive and enforceable legal institutions.

The challenge of price variability to collective marketing can be explained by supply variations and weak market linkages. Reduced supply in rainfed agriculture is generally occasioned by low rainfall or drought occurrences. Investment in water harvesting technologies (eg, watershed management) can be a suitable strategy to mitigate supply variations and subsequent price fluctuations. While unpredictable price fluctuations can be detrimental to collective efforts, seasonal price differences associated with production and supply patterns may be predictable. The PMGs could turn such seasonal price changes to their advantage by storing the grain until the prices are high. This can be effectively done by the PMGs once the binding credit problem has been addressed through alternative 
institutional arrangements. The challenge of low volumes requires a different strategy that would help procure products over a wider catchment area. This requires coordination of marketing functions at a higher level of organization (eg, a union of PMGs) that would also allow spreading of the administrative and logistical costs. Economic viability of PMGs under changing market conditions will also require improvements in business skills and entrepreneurship. This is particularly important at the initial stages when such capacity is lacking. While private service providers may gradually take this role as the PMGs grow, external support would be critical at initial stages to PMGs for training in organization, management, entrepreneurship and marketing functions. The knowledge and skills gained would equip the PMGs with the capacity to initiate and sustain profitable commercial relationships with the private sector and financial institutions (Bingen et al. 2003).

\section{Legal and policy issues for collective marketing}

Given the low level of market development and lack of service providers in many rural areas, the PMGs are unlikely to prosper in a "business as usual" policy environment. An appropriate policy environment that would spur PMG growth will include an enabling legal framework, support to access market information, support to strengthen business skills, and access to essential finance and credit facilities. As is the standard practice for rural groups in Kenya, the PMGs were registered as self-help groups (SHGs) as required by the Kenyan law. Accordingly, the PMGs lack legal status as business enterprises, which is likely to constrain their development and competitiveness under the liberalized market structure. Their registration as social groups rather than business enterprises restricts access to essential credit from formal financial institutions - a major collective marketing constraint identified by the 
PMGs. Their lack of legal status as business enterprises means that they can neither sue nor be sued in case of any liability. This drastically diminishes the incentive for financial institutions to do business with PMGs in terms of providing essential financial services (credit, insurance, etc). Hence, legal recognition as business entities is a prerequisite to place them in a better position for accessing complimentary services which are critical for their development.

Moreover, agricultural marketing systems require rules and regulations that facilitate contract formation and exchange. According to the Kenya Cooperative Societies amendment bill, Article 28, 2004, a cooperative society is required to have a committee of between five and nine members (Republic of Kenya 2004). ${ }^{11}$ The committee is empowered to enter into contracts and carry out other business functions in accordance with the established by-laws. Based on this article, the PMGs can transit quickly from self help groups into cooperative. The act empowers the members to be responsible for their own registered cooperative societies and stress on the need for the cooperatives, through their elected committees, to run their societies in accordance with internationally accepted cooperative principles. The relationship between societies and the government is through the commissioner of cooperatives, who is responsible for the cooperative development and growth and provides organization, registration, operation, advancement and dissolution services. Manyara (2003) argues that government controls are justifiable to restore regulatory controls for the sector to be sustainable, but Argwings-Kodhek (2004) contends that the amendments seem to be

\footnotetext{
${ }^{11}$ The supplement contains amendments to the Cooperatives Act No. 12 of 1997, which, too, was a result of an amendment of the Cooperative Societies Cap. 490 of 1966. In an effort to enhance the policy and legal framework for the functioning of cooperatives, the Kenyan government has gradually introduced these two amendments. The latest amendments were motivated by the need to enable cooperative societies operate as business entities.
} 
referring more to a typical troubled agricultural marketing cooperative or generally a small rural crop marketing-based cooperative. Nevertheless, the amended act would appear to provide for a stronger regulatory framework within which cooperative societies can operate but it fails to provide sufficient mechanism for those now registered as welfare groups to transit into cooperative societies. The strong regulatory framework stipulated in the act without proper mechanisms for facilitating and supporting younger cooperative societies and farmer organizations could also inhibit further development and competitiveness. ${ }^{12}$

A framework that seeks to promote, guide and discipline the operation of markets may also be required to enhance PMG operations. Typical examples will include laws dealing with good agricultural practice, environmental and consumer protection to motivate corporate social responsibility and accountability. Such a framework will need to address constraints to development and sustainability of the PMGs based on their core function of collective marketing which will be critical to their growth and effectiveness. As discussed earlier, low volumes, low business skills and lack of storage facilities are some of the critical constraints to collective marketing. The low volume problem is a further justification for the establishment of an umbrella union or confederation of PMGs which can horizontally and vertically coordinate the marketing functions of the member PMGs. This will be an essential strategy for the PMGs to reduce transaction costs while also reducing their fixed administration costs through better vertical and horizontal coordination of output and input marketing functions.

\footnotetext{
${ }^{12}$ The framework requires that societies elect new office bearers annually, maintain financial statements that meet international standards and prepare and submit annual statement of accounts audited by an auditor approved by the government. Failure to meet these requirements or meet stated objectives may lead to dissolution.
} 


\section{CONCLUSIONS}

Market liberalization is a necessary but not sufficient condition to increase access to markets by smallholder farmers in many countries of sub-Saharan Africa. The expected positive response by the private sector in many areas with limited market infrastructure has however been disappointing, leaving a large number of smallholder farmers under subsistence production and, therefore, unable to benefit from liberalized markets. Structural problems of poor infrastructure and lack of market institutions needed to fill the vacuum left when governments withdrew from markets in the process of liberalization contribute to high transaction costs, coordination failure and pervasive market imperfections. This realization has necessitated new kinds of institutional arrangements to enhance the uptake of marketoriented and productivity-enhancing technologies, link farmers to markets and foster market participation and commercialization of smallholder production. One of these institutional innovations has been the strengthening of producer organizations and formation of collective marketing groups as instruments to remedy pervasive market failures in rural economies.

The analysis presented here has shown that while collective action - embodied in PMGs - is feasible and useful, external shocks and structural constraints in the system require farmer organization and coordination mechanisms at a higher scale to exploit scale economies. Recurrent droughts in semi-arid areas and low productivity of soils reduce marketable surplus and increase vulnerability and attenuate the benefits of collective action. The continued existence of PMGs under such circumstances depends on the ability to organize farmers at a higher level of coordination (eg, district), and their ability to tackle technological and financial problems that now limit crop yields and the amount procured in a given season. 
It is evident that marketing channels in the study areas are characterized by long and complex marketing chains and high transaction costs which considerably lower the farmers' share of the consumer price. Producer marketing groups have the potential to simplify and shorten the marketing chain by directly connecting small producers to secondary and tertiary markets; better coordinate production and marketing activities and facilitate farmer access to production inputs at fair prices. Even so, only relatively successful PMGs will be able to exploit this potential. The effectiveness of this collective action was reflected in the larger volumes of grain transacted and capital assets held by the group. The effectiveness of collective action in terms of these performance indicators was found to be a function of the level of collective action in the form of increased participatory decision making, member contributions to the PMG, and initial start-up capital. Hence, better performing groups in terms of collective marketing, showed evidence of high levels of collective action. The higher the levels of collective action, the more successful the PMGs were in terms of monetized per capita assets built over time and also the per capita grain volumes traded. The number of elections held, initial start-up capital and membership fees were all positively associated with group performance, while the number of villages covered by the PMGs, distances to markets and group size seem to have the opposite effect on group performance.

The challenge therefore is to sensitize members on the democratic principles of participatory group governance through elections, to provide initial start-up capital to kickstart their operations, and to encourage members to increase their registration fees for membership to raise the necessary minimum capital. This calls for interventions that will improve governance and democratization of the PMGs; solicit for external support in establishing a start-up capital base; and encourage increased annual contributions to the 
PMGs by the membership. This will need to be coupled with training of managers and possibly members of the PMGs in business skills to facilitate effectiveness and accountability in running the PMGs as business enterprises. In addition the PMGs have to be registered as legal business entities and not as self-help groups, which restricts their ability to access essential business services.

Although the PMGs demonstrated that they could fill gaps in the marketing channels and pay better prices to farmers, their effectiveness was hampered by their lack of cash capital to pay for produce deliveries by farmers. The brokers and rural wholesalers who can pay cash on delivery were still dominant market participants in rural grain markets. The PMGs on average required some five weeks to pay the farmers after grain delivery. Cash constrained farmers find it very difficult to wait for that long, even when the PMGs' would eventually be in a position to pay prices significantly higher than other buyers. Hence many small producers choose to sell their grain to other traders although this may mean receiving lower prices. Therefore, until the PMGs are able to pay promptly for deliveries made (even if it means a proportion of the final price) small producers will not be in a position to benefit from market opportunities opened through collective action. There is thus a need to enhance the ability of the PMGs to access working capital through access to financial credit. An innovative strategy would be to use the PMG crop inventory before sale as collateral for financial credit and to subsequently encourage formal financial institutions to extend warehouse or inventory credit services to PMGs. This is critical to enable PMGs to overcome the binding liquidity constraints and facilitate effective coordination of the marketing functions for small producers. 
In addition to credit, experiences in eastern Kenya show that collective marketing activities are constrained by low volumes, price variability and low business skills. The formation of an umbrella union of PMGs may help in addressing the problems of low volumes, price variability and the lack of credit. Low transacted volumes are attributed to delivering of small quantities of grain by producers. This may be due to drought conditions, low productivity of traditional agriculture and weak incentives to sell through PMGs. Moreover, the farmers are scattered over a wide area making coordination costly and difficult. This calls for enhanced institutional arrangements for better vertical and horizontal coordination of marketing functions according to manageable spatial units. A union of PMGs (under an umbrella body) may ease the market coordination constraint, thus lowering coordination costs. This option would enable PMGs to vertically coordinate transactions in addition to facilitating access to a broad range of buyers at the upper end of the marketing chain. The seasonal price variability may also be exploited through bulking and storage during periods of excess supply and selling when prices improve as the supply diminishes. The alternative option for smoothing supply will require investments in drought mitigating and water harvesting techniques that would enable farmers in drought-prone areas manage production risk more effectively. External support for strengthening existing institutions and collective investments in integrated watershed management may also generate significant economic and environmental benefits to the affected communities. 
Appendix 1--Producer marketing groups (PMGs) study sites in Kenya
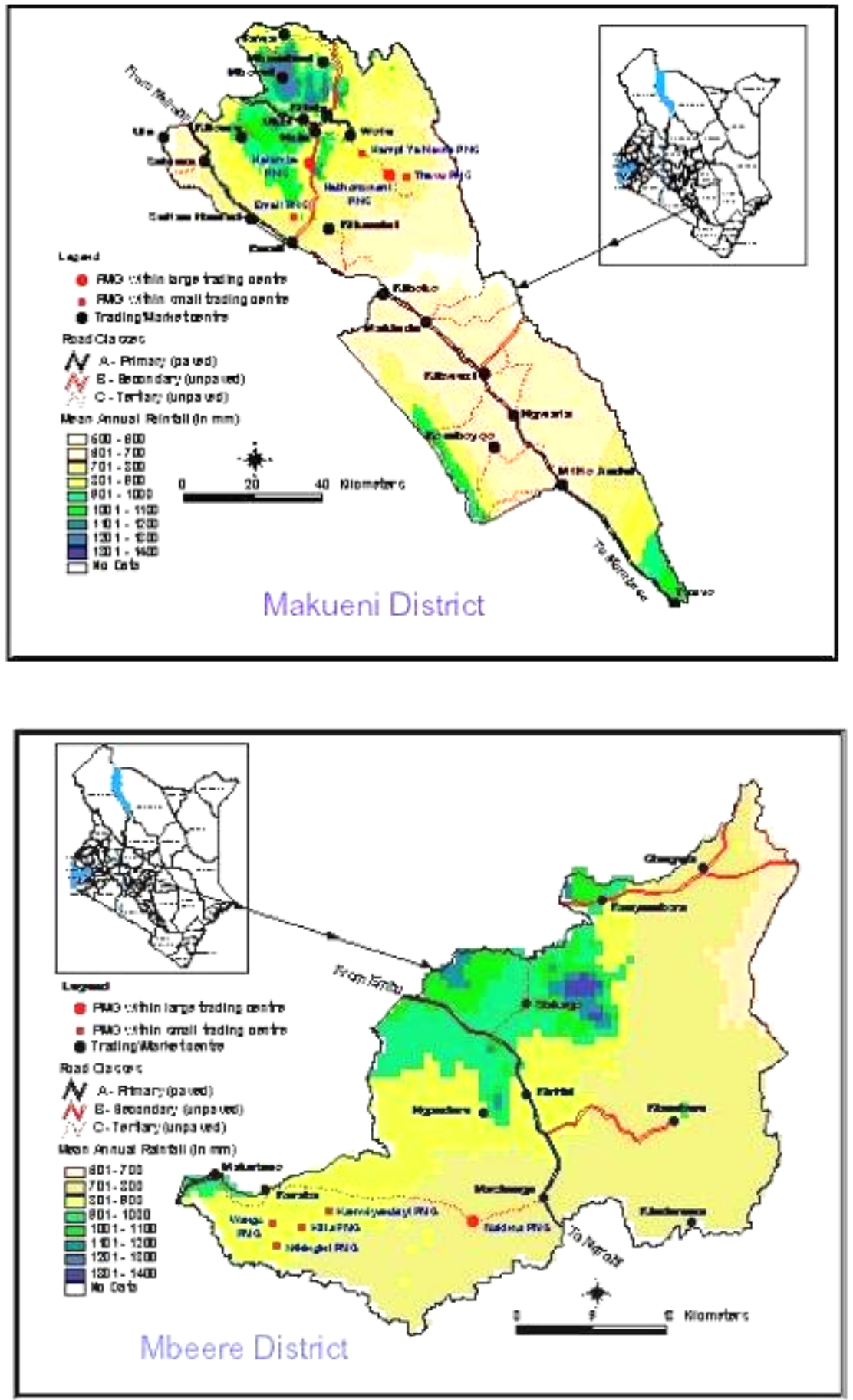
Appendix 2--One-way analysis of variance and test of comparison of means and variances by crop and buyer

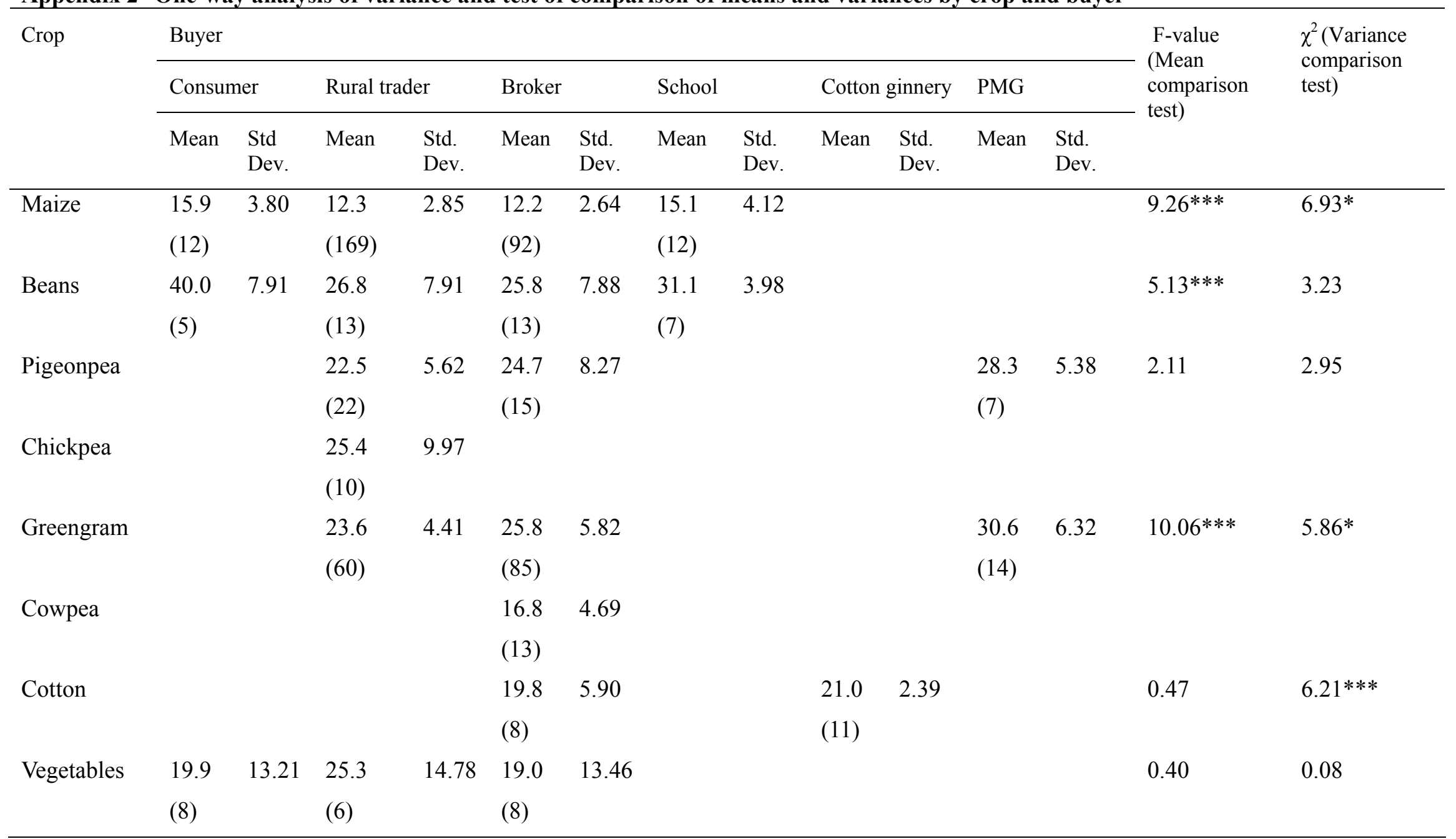

Notes: Buyers with frequency of less than 5 transactions were not considered. Frequencies are in parenthesis.

The last column shows Bartlett's $\chi^{2}$ test statistic for equal price variances between buyers. When price variances significantly differed across buyers, the group variance comparison test was used to compare PMG price variances with other buyers.

***, * significant at $1 \%$ and $10 \%$ levels, respectively.

Source: Household survey 2005 


\section{REFERENCES}

Agrawal A and Goyal S. 2001. Group size and collective action: Third-party monitoring in common-pool resources. Comparative Political Studies 34(1): 63-93.

Akerlof GA. 1970. The market for "lemons": Quality and uncertainty and the market mechanism. Quarterly Journal of Economics 84(3): 488-500.

Akwabi-Ameyaw K. 1997. Producer cooperatives resettlement projects in Zimbabwe: Lessons from a failed agricultural development strategy. World Development 25(3): 437-456.

Argwings-Kodhek G. 2004. Feast and famine: Financial services for rural Kenya. Tegemeo Rural Finance Paper, Tegemeo Institute of Agricultural Policy and Development, Egerton University. http://www.aec.msu.edu/fs2/kenya/wp12-ruralf.pdf.

Bingen J, Serrano A and Howard J. 2003. Linking farmers to markets: Different approaches to human capital development. Food Policy 28: 405-419.

Chowdhury S, Negessa A and Torero M. 2005. Market institutions: Enhancing the value of rural-urban links. FCND Discussion Paper 195/MTID Discussion Paper 89. Washington DC: International Food Policy Research Institute.

Coulter J, Millns J, Tallontire A and Stringfellow R. 1999. Marrying farmer cooperation and contract farming for agricultural service provision in liberalizing economies in subSaharan Africa. ODI Natural Resources Perspectives, No. 48, London: Overseas Development Institute.

de Janvry A, Fafchamps M and Sadoulet E. 1991. Peasant household behaviour with missing markets: Some paradoxes explained. Economic Journal 101:1400-1417.

Dorward A and Kydd J. 2004. The Malawi 2002 food crisis: The rural development challenge. Journal of Modern African Studies 42(3): 343-361.

Dorward A, Fan S, Kydd J, Lofgren H, Morrison J, Poulton C, Rao N, Smith L, Tschale H, Thorat S, Urey I and Wobst P. 2004a. Institutions and policies for pro-poor agricultural growth. Development Policy Review 22(6): 611-622.

Dorward A, Kydd J, Morrison J and Poulton C. 2005. Institutions, markets and economic development: Linking development policy to theory and praxis. Development and Change 36(1): 1-25.

Dorward A, Kydd J, Morrison J and Uray I. 2004b. A policy agenda for pro-poor agricultural growth. World Development 32(1): 73-89.

Dorward A, Poole N, Morrison J, Kydd J and Uray I. 2003. Markets, institutions and technology: Missing links in livelihoods analysis. Development Policy Review 21(3): 319-332. 
Fafchamps M. 2004. Market institutions in sub-Saharan Africa. Cambridge, MA: MIT Press.

Fafchamps M and Minten B. 1999. Relationships and traders in Madagascar. Journal of Development Studies 35(6): 1-35.

Fafchamps M and Hill RV. 2005. Selling at the farmgate or traveling to the market. American Journal of Agricultural Economics 87(3): 717-734.

Gabre-Madhin EZ. 2001. Market institutions, transaction costs, and social capital in the Ethiopian grain market. IFPRI Research Report 124. Washington DC: International Food Policy Research Institute.

Halloway G and Ehui S. 2002. Expanding market participation among smallholder livestock producers. ILRI Socioeconomic and Policy Research, Working paper 48. Nairobi, Kenya: International Livestock Research Institute.

Hoff K. 2001. Beyond Rosenstein-Rodan: The modern theory of coordination problems in development in Proceedings of the Annual World Bank Conference on Development Economics (Boris P and Stern N, eds.). Washington, DC: The World Bank. http://www.wye.ic.ac.uk/AgEcon/ADU/research/projects/farmorg/fosumjul.doc

Hussi P, Murphy J, Lindberg O and Breneeman L. 1993. The development of cooperatives and other rural organizations. Technical Paper No 199. Washington DC: The World Bank.

Jayne T.S. and Jones S. 1997. Food marketing and pricing policy in Eastern and Southern Africa: A survey. World Development 25(9): 1505-1527.

Jayne TS, Govereh J, Mwavumo A, Nyoro JK and Chapoto A. 2002. False promise or false premise? The experience of food and input market reform in Eastern and Southern Africa. World Development 30(11): 1967-1985.

Johnson N and Berdegue JA. 2004. Property rights, collective action and agribusiness. 2020 Focus 11, Brief 13. Washington DC: International Food Policy Research Institute (IFPRI).

Johnson N, Ravnborg HM, Westermann O and Probst K. 2002. User participation in watershed management and research. Water Policy 3(6): 507-520.

Jones R, Freeman HA and Monaco GL. 2002. Improving the access of small farmers in Eastern and Southern Africa to global pigeonpea markets. Agricultural Research and Extension Network Paper 120. London: Overseas Development Institute. http:/www.odi.org.uk/agren/.

Kelly V, Adesina AA and Gordon A. 2003. Expanding access to agricultural inputs in Africa: A review of recent market development experience. Food Policy 28(4): 379-404. 
Kerr J, Pangare G and Lokur V. 2002. Watershed development projects in India. IFPRI Research Report 127. Washington DC: International Food Policy Research Institute.

Key N, Sadoulet E and de Janvry A. 2000. Transaction costs and agricultural household supply response. American Journal of Agricultural Economics 82: 245-259.

Kherallah M, Delgado C, Gabre-Madhin E, Minot N and Johnson M. 2000. The road half traveled: Agricultural market reform in sub-Saharan Africa. Food Policy Report. Washington DC: International Food Policy Institute.

Kindness $\mathrm{H}$ and Gordon A. 2001. Agricultural marketing in developing countries: The role of NGOs and CBOs. Policy Series No. 13. Social and Economic Development Department, Natural Resources Institute, University of Greenwich.

Kirkpatrick C and Maimbo SM. 2002. The implications of the evolving microfinance agenda for regulatory and supervisory policy. Development Policy Review 20(3): 293-304.

Kranton RE. 1996. Reciprocal exchange: A self-sustaining system. American Economic Review 86(4): 830-851.

Kydd J and Dorward A. 2004. Implications of market and coordination failures for rural development in least developed countries. Journal of International Development 16: 951-970.

Lele U. 1981. Cooperatives and the poor: A comparative perspective. World Development 9(1): 55-72.

Lele U and Christiansen RE. 1989. Markets, marketing boards, and cooperatives in Africa: Issues in adjustment policy. Managing Agricultural Development in Africa (MADIA) Discussion Paper II. Washington DC: World Bank.

Manyara MK. 2003. The development of cooperative law and policy in Kenya. Nairobi: Oscan Print.

Marshall G. 1998. A dictionary of sociology. New York, NY: Oxford University Press.

McCarthy N, Dutilly-Diané C and Drabo B. 2002. Cooperation, collective action and natural resources management in Burkina Faso: A methodological note. CAPRi Working Paper No. 27. Washington DC: International Food Policy Research Institute.

Mude A. 2006. Weaknesses in institutional organization: Explaining the performance of Kenya's coffee cooperatives. Paper presented at the $26^{\text {th }}$ IAAE conference, 12-18 August, Brisbane, Australia.

North DC. 1990. Institutions, institutional change and economic performance. Cambridge: Cambridge University Press. 
Place F, Kariuki G, Wangila J, Kristjanson P, Makauki A and Ndubi J. 2002. Assessing the factors underlying differences in group performance: Methodological issues and empirical findings from the highlands of central Kenya. CAPRi Working Paper No. 25. Washington DC. International Food Policy Research Institute.

Poulton C, Kydd J and Dorward A. 2006. Overcoming market constraints on pro-poor agricultural growth in sub-Saharan Africa. Development Policy Review 24(3): 243277.

Poulton C, Dorward A and Kydd J. 1998. The revival of smallholder cash crop in Africa: public and private roles in the provision of finance. Journal of International Development 10(1): 85-103.

Republic of Kenya. 2004. Kenya gazette supplement No. 17, Bill no. 5. Nairobi: Government Printer.

Republic of Kenya. 2000. Second report on poverty in Kenya, Vol. ii. Poverty and social indicators. Nairobi: Ministry of Planning and National Development.

Rondot P and Collion M. 1999. Agricultural producer organizations: Their contribution to rural capacity building and poverty reduction. Summary of a workshop, June 28-30, Washington DC. Rural Development Department, World Bank.

Runge CF. 1981. Common property externalities: Isolation, assurance and resource depletion in traditional grazing context. American Journal of Agricultural Economics 63(4): 595-606.

Staal S, Delgado C and Nicholson C. 1997. Smallholder dairying under transaction costs in East Africa. World Development 25(5): 779-794.

Stockbridge M, Dorward A and Kydd J. 2003. Farmer organizations for market access: Briefing paper presented at Stakeholders Meeting on Farmer Organisations in Malawi. 18-19 June 2003, Kalikuti Hotel, Lilongwe, Malawi. http://www.cphp.uk.com/uploads/disseminations/R8275\%20040516\%20Bfg\%20Pape r\%20FO\%20for $\% 20$ market $\% 20$ access.pdf

Stringfellow R, Coulter J, Lucey T, McKone and Hussain A. 1997. Improving access of smallholders to agricultural services in sub-Saharan Africa: Farmer cooperation and the role of donor community. Natural Resource Perspectives, No 20. London: Overseas Development Institute.

White TA and Runge CF. 1995. The emergence and evolution of collective action: Lessons from watershed management in Haiti. World Development 23(10): 1683-1698.

Winter-Nelson A and Temu A. 2002. Institutional adjustment and transaction costs: Product and input markets in the Tanzania coffee system. World Development 30(4): 561-574. 
Wolf T. 1986. State intervention at the cabbage-roots: A case study from Kenya. IDS Bulletin 17, No. 1: 47-50.

World Bank. 1995. Empowering farmers in sub-Saharan Africa: Best practices. Findings, Africa Region, Number 33. www.worldbank.org/afr/findings/english/find33.htm.

World Bank. 2002a. World development report 2002: Building institutions for markets. New York: Oxford University Press.

World Bank. 2002b. From action to impact: The Africa region's rural strategy. Rural Development Operations, the Africa Region. Washington DC: The World Bank. http://wwwwds.worldbank.org/servlet/WDSContentServer/WDSP/IB/2002/08/09/000094946020072604210882/Rendered/PDF/multi0page.pdf.

World Bank. 2003. World development report 2003: Sustainable development in a dynamic world. New York: Oxford University Press. 


\section{List of CAPRi Working Papers}

01 Property Rights, Collective Action and Technologies for Natural Resource Management: A Conceptual Framework, by Anna Knox, Ruth Meinzen-Dick, and Peter Hazell, October 1998.

02 Assessing the Relationships between Property Rights and Technology Adoption in Smallholder Agriculture: A Review of Issues and Empirical Methods, by Frank Place and Brent Swallow, April 2000.

03 Impact of Land Tenure and Socioeconomic Factors on Mountain Terrace Maintenance in Yemen, by A. Aw-Hassan, M. Alsanabani and A. Bamatraf, July 2000 .

04 Land Tenurial Systems and the Adoption of a Mucuna Planted Fallow in the Derived Savannas of West Africa, by Victor M. Manyong and Victorin A. Houndékon, July 2000 .

05 Collective Action in Space: Assessing How Collective Action Varies Across an African Landscape, by Brent M. Swallow, Justine Wangila, Woudyalew Mulatu, Onyango Okello, and Nancy McCarthy, July 2000.

06 Land Tenure and the Adoption of Agricultural Technology in Haiti, by Glenn R. Smucker, T. Anderson White, and Michael Bannister, October 2000.

07 Collective Action in Ant Control, by Helle Munk Ravnborg, Ana Milena de la Cruz, María Del Pilar Guerrero, and Olaf Westermann, October 2000.

08 CAPRi Technical Workshop on Watershed Management Institutions: A Summary Paper, by Anna Knox and Subodh Gupta, October 2000.

09 The Role of Tenure in the Management of Trees at the Community Level: Theoretical and Empirical Analyses from Uganda and Malawi, by Frank Place and Keijiro Otsuka November 2000.

10 Collective Action and the Intensification of Cattle-Feeding Techniques a Village Case Study in Kenya's Coast Province, by Kimberly Swallow, November 2000.

11 Collective Action, Property Rights, and Devolution of Natural Resource Management: Exchange of Knowledge and Implications for Policy, by Anna Knox and Ruth Meinzen-Dick, January 2001. 
12 Land Dispute Resolution in Mozambique: Evidence and Institutions of Agroforestry Technology Adoption, by John Unruh, January 2001.

13 Between Market Failure, Policy Failure, and "Community Failure": Property Rights, Crop-Livestock Conflicts and the Adoption of Sustainable Land Use Practices in the Dry Area of Sri Lanka, by Regina Birner and Hasantha Gunaweera, March 2001.

14 Land Inheritance and Schooling in Matrilineal Societies: Evidence from Sumatra, by Agnes Quisumbing and Keijuro Otsuka, May 2001.

15 Tribes, State, and Technology Adoption in Arid Land Management, Syria, by Rae, J, Arab, G., Nordblom, T., Jani, K., and Gintzburger, G., June 2001.

16 The Effects of Scales, Flows, and Filters on Property Rights and Collective Action in Watershed Management, by Brent M. Swallow, Dennis P. Garrity, and Meine van Noordwijk, July 2001.

17 Evaluating Watershed Management Projects, by John Kerr and Kimberly Chung, August 2001.

18 Rethinking Rehabilitation: Socio-Ecology of Tanks and Water Harvesting in Rajasthan, North-West India, by Tushaar Shah and K.V.Raju, September 2001.

19 User Participation in Watershed Management and Research, by Nancy Johnson, Helle Munk Ravnborg, Olaf Westermann, and Kirsten Probst, September 2001.

20 Collective Action for Water Harvesting Irrigation in the Lerman-Chapala Basin, Mexico, by Christopher A. Scott and Paul Silva-Ochoa, October 2001.

21 Land Redistribution, Tenure Insecurity, and Intensity of Production: A Study of Farm Households in Southern Ethiopia, by Stein Holden and Hailu Yohannes, October 2001.

22 Legal Pluralism and Dynamic Property Rights, by Ruth Meinzen-Dick and Rajendra Pradhan, January 2002.

23 International Conference on Policy and Institutional Options for the Management of Rangelands in Dry Areas, by Tidiane Ngaido, Nancy McCarthy, and Monica Di Gregorio, January 2002.

24 Climatic Variablity and Cooperation in Rangeland Management: A Case Study From Niger, by Nancy McCarthy and Jean-Paul Vanderlinden, September 2002. 
25 Assessing the Factors Underlying the Differences in Group Performance:

Methodological Issues and Empirical Findings from the Highlands of Central Kenya, by Frank Place, Gatarwa Kariuki, Justine Wangila, Patti Kristjanson, Adolf Makauki, and Jessica Ndubi, November 2002.

26 The Importance of Social Capital in Colombian Rural Agro-Enterprises, by Nancy Johnson, Ruth Suarez, and Mark Lundy, November 2002.

27 Cooperation, Collective Action and Natural Resources Management in Burkina Faso: A Methodological Note, by Nancy McCarthy, Céline Dutilly-Diané, and Boureima Drabo, December 2002.

28 Understanding, Measuring and Utilizing Social Capital: Clarifying Concepts and Presenting a Field Application from India, by Anirudh Krishna, January 2003.

29 In Pursuit Of Comparable Concepts and Data, about Collective Action, by Amy Poteete And Elinor Ostrom, March 2003.

30 Methods of Consensus Building for Community Based Fisheries Management in Bangladesh and the Mekong Delta, by Parvin Sultana and Paul Thompson, May 2003.

31 Formal and Informal Systems in Support of Farmer Management of Agrobiodiversity: Some Policy Challenges to Consolidate Lessons Learned, by Marie Byström, March 2004.

32 What Do People Bring Into the Game: Experiments in the Field About Cooperation in the Commons, by Juan-Camilo Cárdenas and Elinor Ostrom, June 2004.

33 Methods for Studying Collective Action in Rural Development, by Ruth MeinzenDick, Monica Di Gregorio, and Nancy McCarthy, July 2004.

34 The Relationship between Collective Action and Intensification of Livestock Production: The Case of Northeastern Burkina Faso, by Nancy McCarthy, August 2004.

35 The Transformation of Property Rights in Kenya's Maasailand: Triggers and Motivations by Esther Mwangi, January 2005.

36 Farmers' Rights and Protection of Traditional Agricultural Knowledge, by Stephen B. Brush, January 2005. 
37 Between Conservationism, Eco-Populism and Developmentalism - Discourses in Biodiversity Policy in Thailand and Indonesia, by Heidi Wittmer and Regina Birner, January 2005.

38 Collective Action for the Conservation of On-Farm Genetic Diversity in a Center of Crop Diversity: An Assessment of the Role of Traditional Farmers' Networks, by Lone B. Badstue, Mauricio R. Bellon, Julien Berthaud, Alejandro Ramírez, Dagoberto Flores, Xóchitl Juárez, and Fabiola Ramírez, May 2005.

39 Institutional Innovations Towards Gender Equity in Agrobiodiversity Management: Collective Action in Kerala, South India, by Martina Aruna Padmanabhan, June 2005.

40 The Voracious Appetites of Public versus Private Property: A View of Intellectual Property and Biodiversity from Legal Pluralism, by Melanie G. Wiber, July 2005.

41 Who Knows, Who Cares? Determinants of Enactment, Awareness and Compliance with Community Natural Resource Management Bylaws in Uganda, by Ephraim Nkonya, John Pender, Edward Kato, Samuel Mugarura, and James Muwonge, August 2005.

42 Localizing Demand and Supply of Environmental Services: Interactions with Property Rights, Collective Action and the Welfare of the Poor, by Brent Swallow, Ruth Meinzen-Dick, and Meine von Noordjwik, September 2005.

43 Initiatives for Rural Development through Collective Action: The Case of Household Participation in Group Activities in the Highlands of Central Kenya, By Gatarwa Kariuki and Frank Place, September 2005.

44 Are There Customary Rights to Plants? An Inquiry among the Baganda (Uganda), with Special Attention to Gender, by Patricia L. Howard and Gorettie Nabanoga, October 2005.

45 On Protecting Farmers' New Varieties: New Approaches to Rights on Collective Innovations in Plant Genetic Resources by Rene Salazar, Niels P. Louwaars, and Bert Visser, January 2006.

46 Subdividing the Commons: The Politics of Property Rights Transformation in Kenya’s Maasailand, by Esther Mwangi, January 2006.

47 Biting the Bullet: How to Secure Access to Drylands Resources for Multiple Users, by Esther Mwangi and Stephan Dohrn, January 2006. 
48 Property Rights and the Management of Animal Genetic Resources, by Simon Anderson and Roberta Centonze, February 2006.

49 From the Conservation of Genetic Diversity to the Promotion of Quality Foodstuff: Can the French Model of 'Appellation d'Origine Contrôlée' be Exported? by Valérie Boisvert, April 2006.

50 Facilitating Collective Action and Enhancing Local Knowledge: A Herbal Medicine Case Study in Talaandig Communities, Philippines, by Herlina Hartanto and Cecil Valmores, April 2006.

51 Water, Women and Local Social Organization in the Western Kenya Highlands, by Elizabeth Were, Brent Swallow, and Jessica Roy, July 2006.

52 The Many Meanings of Collective Action: Lessons on Enhancing Gender Inclusion and Equity in Watershed Management, by Laura German, Hailemichael Taye, Sarah Charamila, Tesema Tolera, and Joseph Tanui, July 2006.

53 Decentralization and Environmental Conservation: Gender Effects from Participation in Joint Forest Management, by Arun Agrawal, Gautam Yadama, Raul Andrade, and Ajoy Bhattacharya, July 2006.

54 Improving the Effectiveness of Collective Action: Sharing Experiences from Community Forestry in Nepal, by Krishna P. Achyara and Popular Gentle, July 2006.

55 Groups, Networks, and Social Capital in the Philippine Communities, by Marie Godquin and Agnes R. Quisumbing, October 2006.

56 Collective Action in Plant Genetic Resources Management: Gendered Rules of Reputation, Trust and Reciprocity in Kerala, India, by Martina Aruna Padmanabhan, October 2006.

57 Gender and Local Floodplain Management Institutions--A case study from Bangladesh, by Parvin Sultana and Paul Thompson, October 2006.

58 Gender Differences in Mobilization for Collective Action: Case Studies of Villages in Northern Nigeria, by Saratu Abdulwahid, October 2006.

59 Gender, Social Capital and Information Exchange in Rural Uganda, by Enid Katungi, Svetlana Edmeades, and Melinda Smale, October 2006. 